\title{
Displacement accumulation during paleoearthquakes for active normal faults on the eastern Mediterranean island of Crete
}

\section{Authors}

Nicol, A.(1), Mouslopoulou, V.(2*), Begg, J.(3), Oncken, O.(4)

(1) School of Earth and Environment, University of Canterbury, Private Bag 4800, Christchurch, New Zealand (andy.nicol@canterbury.ac.nz )

(2) National Observatory of Athens, Institute of Geodynamics, Lofos Nimfon, Athens, 11810, Greece (vasiliki.mouslopoulou@noa.gr)

(3) GNS Science, Lower Hutt, PO Box 60-368, New Zealand (J.Begg@gns.cri.nz)

(4) Deutsches GeoForschungsZentrum GFZ, Telegrafenberg, Potsdam, 14473, Germany (onno@gfz-potsdam.de)

(*) Also at Deutsches GeoForschungsZentrum GFZ, Telegrafenberg, Potsdam, 14473, Germany

Keywords

normal faults, Crete, paleoearthquakes, sampling biases, displacement accumulation, displacement rates, single-event displacements, earthquake recurrence intervals. 


\section{Displacement accumulation during paleoearthquakes for active normal faults on the eastern Mediterranean island of Crete}

Nicol, A. ${ }^{1}$, Mouslopoulou, V. ${ }^{2 *}$, Begg, ${ }^{3}{ }^{3}$, Oncken, $0 .{ }^{4}$

${ }^{1}$ School of Earth and Environment, University of Canterbury, Private Bag 4800, Christchurch, New Zealand (andy.nicol@canterbury.ac.nz )

${ }^{2}$ National Observatory of Athens, Institute of Geodynamics, Lofos Nimfon, Athens, 11810, Greece (vasiliki.mouslopoulou@noa.gr)

33GNS Science, Lower Hutt, PO Box 60-368, New Zealand (J.Begg@gns.cri.nz)

${ }^{4}$ Deutsches GeoForschungsZentrum GFZ, Telegrafenberg, Potsdam, 14473, Germany (onno@gfz-potsdam.de)

*Also at Deutsches GeoForschungsZentrum GFZ, Telegrafenberg, Potsdam, 14473, Germany

\section{Abstract}

Active normal faults on the eastern Mediterranean island of Crete form prominent limestone scarps together with basin and range topography. These faults mainly strike E-ESE and N-NNE in southern and northern Crete, respectively, with fault sets commonly intersecting and northern-trending faults a factor of three more abundant. Displacements, lengths and displacement rates have been analysed for 84 active faults sampled over $2 \pm 0.5 \mathrm{Ma}$ (long term) and $16.5 \pm 2 \mathrm{ka}$ (short term) time-intervals, with about half showing no resolvable short-term activity. Active faults record earthquake processes on timescales of thousands to millions of years and constrain sampling biases, which can lead to under and over estimates of the numbers, rupture lengths, recurrence intervals and single event displacements of paleoearthquakes. The available data indicate no fault propagation and, for the Quaternary, 
higher displacement rates on longer faults, supporting a model in which fault lengths and maximum earthquake magnitudes were established early in the development of the fault system. Short-term displacement rates (0.09-1.2 mm/yr) are generally higher than long-term rates $(0.002-0.7 \mathrm{~mm} / \mathrm{yr})$, with a factor of four disparity in the average recurrence intervals for the two time periods ( $2.5 \mathrm{kyr}$ vs $\sim 11 \mathrm{kyr}$ ). We attribute these differences to 'clustering' of $>$ Mw 6 earthquakes on individual faults over millennial timescales, and to preferential sampling of the most seismically active faults in the post- 16.5 kyr time interval (i.e. faults with highest displacement rates or mid 'cluster'). Displacement rates are comparable when averaged for each time interval on the longest faults $(>10 \mathrm{~km})$, interpreted to indicate that for these faults earthquake 'clustering' spans time-intervals of $16.5 \pm 2 \mathrm{kyr}$ or less. Paleoarthquakes $>$ Mw 6 on Crete are a factor of three more frequent than historical events for the last $100 \mathrm{yrs}$, which could be partly due to paleoevents rupturing multiple faults, either in the same event or in triggered slip events.

Keywords; normal faults, Crete, paleoearthquakes, sampling biases, displacement accumulation, displacement rates, single-event displacements, earthquake recurrence intervals.

\section{Introduction}

Active fault traces generally form due to displacement of the ground surface or seabed during surface-rupturing earthquakes (Gilbert, 1884; Wallace, 1987; Stein et al., 1988; McCalpin, 2009) (Fig. 1). Repeated surface-rupturing earthquakes can produce topography, the height of which depends on the total fault displacement and the relative rates of fault displacement and surface processes (i.e. deposition or erosion) (Fig.1 block diagram). Where sedimentation 
rates exceed fault displacement rates, the faults are buried and their growth histories can be recovered from sub-surface information including, seismic reflection lines and trenches (Sieh et al., 1978; Childs et al., 2003; Nicol et al., 2005; McCalpin, 2009; Mouslopoulou et al., 2012). In cases where the rates of surface process are low relative to fault displacement rates, topography can provide a useful proxy for total fault displacement on geological timescales (e.g., Doutsos \& Poulimenos, 1992; Roberts et al., 2002; Veliz et al., 2018) (Fig. 1, block diagram). For normal faults, such topography occurs in many areas of mainly terrestrial crustal extension including, the Basin and Range (Pierce and Morgan, 1992; Friedrich et al., 2004), the East Africa Rift (Morley, 1999; Manighetti et al., 2015), the Apennines (Roberts et al., 2002), the Gulf of Corinth (Poulimenos, 2000; Gawthorpe et al., 2018) and the Taupo Rift in New Zealand (Nicol et al., 2006, 2010). Many of these systems also contain active fault traces that record displacements arising from small numbers of earthquakes (e.g., <10) which displaced the ground surface (Benedetti et al., 2003; Friedrich et al., 2004). In such cases, comparison of Late Quaternary displacements from fault scarps that define active traces and Plio-Pleistocene fault displacements along individual faults, permits the characterisation of earthquake processes on timescales ranging from hundreds to millions of years (Wallace, 1987; Stein et al., 1988; Nicol et al., 1997, 2005, 2009, 2010; Friedrich et al., 2004; Mouslopoulou et al., 2009, 2012; Veliz et al., 2018) (Fig. 1b \& c).

In this paper we use a combination of millennial and million-year displacements to analyse surface-rupturing earthquakes for active normal faults on the eastern Mediterranean island of Crete. Utilising these two datasets provides a means of assessing and addressing the sampling biases commonly associated with paleoearthquake data, of defining the variability of earthquake processes, and of examining the role of earthquakes in fault development on timescales up to millions of years. The normal faults studied are developing in the overriding 
Eurasian plate due to oblique subduction and rollback of the North Africa plate along the Hellenic margin (McClusky et al., 2000; Caputo et al., 2006; Reilinger et al., 2006, Jolivet et al., 2013) (Fig. 2c). Surface-rupturing earthquakes produced widespread limestone fault scarps following the Last Glaciation Maximum (Fig. 3), while Quaternary displacements of normal faults generated basin and range topography (Figs 2, 4-6) (Caputo et al., 2006, 2010; Mouslopoulou et al., 2014; Mason et al., 2016). Fault and earthquake analysis has been conducted using maximum displacements, trace lengths and displacement rates averaged since $\sim 2 \mathrm{Ma}$ and from $16.5 \pm 2 \mathrm{ka}$ to the present using a topographic proxy for displacement and displacements derived from active fault scarps, respectively (Fassoulas, 2001; Fassoulas and Nikolakakis, 2005; Mouslopoulou et al., 2014; Veliz et al., 2018) (Figs 1, 4-6). Fault data have been augmented by historical seismicity from the written (last 2000 years; Papadopoulos, 2011) and instrumental (1964-2018; National Observatory of Athens) records, and collectively afford information on earthquakes spanning timescales of days to millions of years. The use of datasets spanning different time intervals offers the opportunity to improve understanding of earthquake processes and seismic hazards that would not be possible using the individual datasets alone. Our results may have application to other areas of active normal faulting, both within Greece and elsewhere.

\section{Normal Fault Setting}

Active normal faults on Crete are interpreted to have formed in response to rollback of the subducting African plate along the Hellenic subduction margin (Jolivet et al., 2013) (Fig. 2c). Crete forms part of the sub-aerial forearc of the Eastern Mediterranean Hellenic subduction margin, which accommodates $35-40 \mathrm{~mm} / \mathrm{yr}$ of oblique convergence between the African and Eurasian plates (Fig. 2, inset) (McClusky et al., 2000; Reilinger et al., 2006; Floyd et al., 2010). 
Subduction processes produce small to moderate (e.g., <M5) thrust and strike-slip events in the deeper crust $(>20 \mathrm{~km}$ ) beneath Crete and normal-fault focal mechanisms in the overlying upper crust $(<20 \mathrm{~km})$ (Kiratzi and Louvari, 2003; Konstantinou et al., 2017). Despite this seismicity, plate convergence beneath Crete (Reilinger et al., 2006; Floyd et al., 2010; Vernant et al., 2014), GPS data suggest that local slip-rate deficits of up to $85 \%$ of the total convergence rate are accommodated by aseismic slip on the main subduction thrust and/or splay-thrust faults (Saltogianni et al., in review). Further, GPS data reveal that the marginnormal component of the relative Eurasian-Africa plate motion decreases from west to east along Crete, with extensional kinematics dominating in eastern Crete (Reilinger et al., 2006; Floyd et al., 2010). The landscape (e.g. topography) along Crete is consistent with the contemporary kinematics of deformation, suggesting that active normal faulting may have been operating over million-year timescales (Fassoulas, 2001; Fassoulas and Nikolakakis, 2005; Veliz et al., 2018). The landscape in western Crete is mountainous (e.g. White Mountains; Fig. 2b) and compatible with mainly contraction in the subduction zone with limited normal faulting in the upper plate (Shaw and Jackson, 2010; Mouslopoulou et al., 2015a). By contrast, eastern Crete is dominated by basin and range topography which formed mainly in response to active normal faulting in the upper crust (Fassoulas, 2001; Caputo et al., 2010; Mason et al., 2016; Veliz et al., 2018) (Figs 2-5). As a consequence, the density, size and rates of active normal faulting on Crete increase eastwards (Fig. 2).

Active normal faults in onshore Crete have been mapped in the field (Fassoulas, 1999, 2001; Caputo et al., 2006, 2010; Mountrakis et al., 2012; Gallen et al., 2014; Mouslopoulou et al., 2014; Mason et al., 2016; Veliz et al., 2018; Ganas et al., 2018; this study), and using a high-resolution ( $5 \mathrm{~m}$ ) digital elevation model (DEMs) (this study). Active normal faulting in the surrounding offshore regions is identified using seismic-reflection and multi-beam 
bathymetry data (Kokinou et al., 2012; Sakellariou et al., 2018), and supported by microseismicity recorded by ocean bottom seismographs (Becker et al., 2010). Some of these active faults are probably reactivated faults formed in response to N-S and E-W extension during Middle and Late Miocene, respectively (Angelier et al., 1982; Fassoulas, 1999, 2001; Caputo et al., 2010; Mouslopoulou et al., 2014). The present phase of extension commenced in the Quaternary ( 2 $2 \pm 0.5 \mathrm{Ma}$; Fassoulas, 2001), producing mostly E-W striking normal faults in southern Crete and more northerly striking normal faults in northern and western Crete (Fig. 2).

Active normal faults are marked by prominent scarps, which can be observed throughout Crete and are best preserved where they traverse outcrops of Mesozoic limestone (Papastamatiou, 1959; Caputo et al., 2006, 2010; Mountrakis et al., 2012; Mouslopoulou et al., 2014) (Figs $1 \& 3$ ). These fault scarps are up to $\sim 20 \mathrm{~m}$ high and $\sim 40 \mathrm{~km}$ long (Figs. 3, 4 \& 5). Field mapping indicates that the scarps represent exposed fault planes that have dips of $63 \pm 10^{\circ}(1 \sigma)$, with mainly N-NE and ESE-E-ENE strikes (Figs. 2, 4 \& 5a-c). The active fault scarps are typically discontinuous and run along the mid to lower slopes of ridges or mountain range fronts, often separating topographic highs from nearby basins, and accommodate normal dip-slip (Caputo et al., 2010; Mouslopoulou et al., 2014; Mason et al., 2016; Veliz et al., 2018). The spatial and geometric relationships between normal fault scarps and topography are illustrated in Figures 1, 4, 6 and 7 (the trends of fault scarps are marked by lines on the hillshade models in Figs $4 \& 6$ ), and their parallelism is consistent with the notion that Quaternary fault displacements produced both the scarps and the topography. Mirabello Bay in eastern Crete (Fig. 2a) and the Messara Basin in south-central Crete (Fig. 4a) are examples of basin and range topography forming in response to normal faulting. Where N-NE and ESE-E-ENE fault sets intersect they often abut or terminate against each other (Fig. 
6), indicating that the intersecting active fault sets are likely to interact on earthquake timescales (i.e. via co-seismic slip during individual earthquakes or by triggered slip). Active normal faults may also intersect (or step) along strike, with individual structures locally varying in strike by $10-20^{\circ}$ (see, for example, the southern boundary of Messara Basin in Fig. 4b). For the purposes of this study the mapped active faults are treated as individual structures, although it remains possible that in some cases they accrue slip together in the same surface-rupturing events or in events closely spaced in geological time (e.g., $<100$ years) (see Implications for seismic hazard section for further discussion).

Active fault scarps are assumed to have formed during surface-rupturing earthquakes (Fig. 1). Similar limestone fault scarps are observed in Italy, mainland Greece and western Turkey, where they ruptured during historical earthquakes (Benedetti et al., 2003, 2013; Mechernich et al., 2018; Mozafari et al., 2019). We follow previous work in suggesting that the active scarps in Crete record co-seismic rupture of the ground surface following the Last Glacial Maximum time interval. We refer to these fault scarps as post glacial to establish their approximate age in a global context and in doing so are not inferring that glacial processes were widespread on Crete in the last hundred thousand years. In Crete, and the wider in the Eastern Mediterranean region, post-glacial fault scarps and multiple paleoseismic studies are interpreted to indicate that numerous large-magnitude (>Mw6) earthquakes ruptured the ground surface (Mitchell et al., 2001; Benedetti et al., 2003, 2013; Hughes et al., 2006; Caputo et al., 2006, 2010; Mouslopoulou et al., 2014; Mason et al., 2016; Veliz et al., 2018). The age of active fault scarps in Greece and western Turkey is primarily constrained by cosmogenic dating which suggests that climatic conditions were favourable for scarp formation from 16.5 \pm 2 ka to the present day (Benedetti et al., 2003, 2013; Mouslopoulou et al., 2014; Mechernich et al., 2018; Mozafari et al., 2019). Therefore, for the purposes of this study we 
assume that fault scarps record surface-rupturing earthquakes between $16.5 \pm 2 \mathrm{ka}$ and today (for detailed discussion of scarp ages see also Veliz et al., 2018). All limestone fault scarps encountered on Crete are considered to result from the accumulation of one or more groundrupturing earthquakes since $16.5 \pm 2 \mathrm{ka}$, with the resultant displacements being averaged over this time-period to produce displacement rates.

The earthquake-slip model for scarp formation in Crete is consistent with observations from cultural strain markers (e.g., roads and fences) constructed last century that show no evidence of creep at the ground surface on active faults. In addition, both historical earthquakes and cosmogenic dating of limestone fault scarps in Greece indicate that the majority of slip accrues during discrete slip events (i.e. earthquakes) (Benedetti et al., 2003; Mouslopoulou et al., 2014; Mechernich et al., 2018). Therefore, we assume that most of the observed displacement recorded by fault scarps was co-seismic although, given the available data, minor (e.g., $<30 \mathrm{~cm}$ ) sub-resolution creep cannot be discounted, particularly in the days to years following surface-rupturing events. Despite the abundant geological evidence for past ground-rupturing earthquakes, no large $(M>5.5)$ earthquake has occurred onshore Crete during the last 55 years (see Data and Resources). Further, none of the 11 earthquakes of >M6 reported by Papadopoulos (2011) to have occurred beneath onshore Crete during the last $\sim 2000$ years have been unequivocally correlated with individual surface ruptures (Jusseret and Sintubin, 2012; Jusseret et al., 2013; Mouslopoulou et al., 2014).

\section{Data and Sampling}

Active normal faults have been studied here using a combination of displacements along active fault scarps and the topographic height of range fronts along faults (Figs 1, 3, 4, 6 \& 7). The locations, map geometries, lengths, displacements and displacement rates have been 
determined for 84 individual normal faults with active fault scarps and/or their topographic expression measured using a combination of field observations, high-resolution DEM (5 m pixel size and $2 \mathrm{~m}$ vertical resolution - data derived from the Greek Cadastre) and Google Earth images (Figs 1, 3-7). About half ( $\mathrm{N}=44$; Fig. 2) of these faults are characterised by measurements from both active scarps and their topographic expression, with basin and range topography being most common for the larger faults in eastern Crete (e.g., finite displacements of c. $1 \mathrm{~km}$ ) (Figs 4 \& 5). The remaining faults studied ( $N=40 ;$ Fig. 2) have clear topographic expression, but no observable post-glacial active fault trace. The geomorphic expression of range fronts associated with active fault scarps and not associated with active scarps are comparable, with both generally having steep slopes, triangular faceted ridges and perched valleys in the uplifted footwall blocks (e.g., Fig. 3d \& 3e). These geomorphic features are consistent with active faulting along these range fronts and we propose that all of the faults sampled accommodated Quaternary normal faulting. In such cases, faults with no clear post-glacial expression either did not rupture the ground surface during the last $16.5 \pm 2 \mathrm{ka}$, or produced surface displacement during the post-glacial time interval that could not be resolved with the available data, either because they were too small or because they were subsequently modified by surface processes.

\section{Fault displacements}

Displacements for active fault scarps were measured in the field using laser range finder $(\sim \pm 0.3 \mathrm{~m})$ and tape measure $(\sim \pm 0.2 \mathrm{~m})$, and from topographic profiles across scarps in the $\operatorname{DEM}(\sim \pm 1 \mathrm{~m})$. Although these data permit scarp heights of as little as $\sim 1 \mathrm{~m}$ to be recorded in the field, based on the decrease in the number of faults with scarps $<\sim 3 \mathrm{~m} \mathrm{high}$ and $<2 \mathrm{~km}$ long (Figs. $5 \mathrm{~d} \&$ e) we believe that our data set is probably incomplete below these values. 
The incompleteness is partly due to erosion and deposition along fault scarps, which generally make the active faults more difficult to observe, particularly where the scarp heights are small (e.g., $<5 \mathrm{~m}$ ). Local erosion and deposition along post-glacial fault scarps can also modify their heights (Mason et al., 2016; Veliz et al., 2018) (Fig. 3e); to reduce the impact of this potential sampling error, scarp heights were sampled from locations where they do not appear to have been modified by natural or anthropogenic surface processes. In addition, to decrease the impact of unidentified modifications to the scarps, heights were measured at multiple locations (e.g., 3-5 measurements along trace lengths of 200-500 m) along strike, with the values presented in Figure $5 d$ being averages (i.e. the average of the maximum throw). At localities where the main slip surface splays into secondary strands, the vertical displacements were aggregated to produce a total value (e.g., Veliz et al., 2018). Fault-scarp heights are estimated to record the maximum fault vertical displacement that accumulated due to surface-breaking earthquakes since $16.5 \pm 2 \mathrm{ka}$ (Mouslopoulou et al., 2014). This age was used in combination with the displacement accrued on each fault due to these earthquakes to estimate the maximum vertical displacement rate since the onset of scarp formation (i.e., displacements are averaged over $16.5 \pm 2 \mathrm{ka}$ ).

Topographic altitude changes across range-fronts defined by normal faults have been measured from strike-perpendicular profiles and are inferred to provide a measure of millionyear displacements and displacement rates for the Quaternary (Figs 3-8). As with the active scarp measurements, the maximum altitude change across each fault was averaged from multiple profiles (e.g., 2-4 profiles) and provides a proxy for the maximum displacement. Although the rates of erosion of fault footwalls and deposition in hangingwall basins appear to be low in the Quaternary (e.g., $<0.1 \mathrm{~mm} / \mathrm{yr}$ ), measurement of topography could produce under estimates of maximum displacement due to surface processes (Veliz et al., 2018). 
Quaternary displacements could also be over-estimated if topography predated the onset of faulting, however, Crete was mostly submerged prior to $2 \mathrm{Ma}$ and there is presently no evidence from the stratigraphy or analysis of drainage patterns to support significant topography immediately prior to the onset of normal faulting at 2 Ma (Meulenkamp et al., 1994; Roberts et al., 2013). To examine further the impact of pre-existing topography or synfulting erosion and deposition on our estimates of Quaternary displacements we use two cross-sections from the literature to compare displacement of stratigraphy with the change in the height of topography across two active N-S trending faults (Mountrakis et al., 2012; Mason et al., 2016) (Fig. 7). These cross sections show that for N-S faults topographic height provides a reasonable proxy for fault vertical displacement. $D / L$ data show that the Quaternary displacements for E-W faults plot along the D/L trend line defined by the N-S faults (Fig. S1), supporting the inference that topographic height also provides a usable estimate of displacement for E-W faults. For the examples presented in Fig. 7 the displacement of stratigraphy is $<20 \%$ greater than the height of topography which supports the use of topography as a first-order measure of the maximum displacement. Nevertheless, for the purposes of this study we are conservative and allow uncertainties of $+40 \%$ and $-20 \%$ for maximum displacements derived from topography, which are inferred to account for measurement uncertainties and the influence of surface processes. These maximum displacements are used in conjunction with an estimated age of $\sim 2 \pm 0.5 \mathrm{Ma}$ for the onset of extension (Fassoulas, 2001) to calculate average displacements rates for the Quaternary (for further discussion see Veliz et al., 2018).

\section{Fault lengths}


Fault length is a key parameter for estimating the dimensions of faults and earthquake ruptures, seismic moments and earthquake magnitudes (e.g., Wells and Coppersmith, 1994; Wesnousky, 2008). Measurement of the lengths of active faults that ruptured prehistorically can be subject to significant uncertainty because fault scarps are prone to erosion and burial, earthquakes may not break the ground surface along their entire length at depth, and displacements at fault tips are typically too small to be detected because the vertical resolution of traditional field mapping or aerial photo analysis is generally $0.5-1 \mathrm{~m}$. For these reasons, the lengths of active faults and paleoearthquake ruptures are considered to be minimums, with lengths under estimated by, in some cases, more than $50 \%$ (Wesnousky, 2008; McCalpin, 2009; Mouslopoulou et al., 2012; Nicol et al., 2016a; Biasi and Wesnousky, 2017). We believe that such under estimates also apply to some measurements of active-fault lengths on Crete. In an attempt to take account of this under estimation of active fault lengths we have measured both the length of fault scarps (referred to here as post-glacial scarp length) and the length of topography interpreted to have been produced by each fault (referred to here as Quaternary topographic length). The plot in Figure 5e compares the two measurements and shows that Quaternary topographic lengths are always equal to $(\mathrm{N}=3)$ or greater than $(\mathrm{N}=41)$ post-glacial scarp lengths, with these differences being up to a factor of ten (Fig. 5e); on average, topographic lengths are 2.5 times greater than scarp lengths. For the available Crete data, the shorter post-glacial lengths are considered to primarily arise due to sampling artefacts. Therefore, here we use topographic lengths for estimating paleoearthquake parameters including, single event displacement (SED), earthquake recurrence interval $(\mathrm{RI})$ and moment magnitude $(\mathrm{Mw})$. Although more robust than the scarp lengths, these topographic lengths are also subject to uncertainties of up to \pm 500 m due to errors in locating fault tips. In addition, twenty-three of the mostly longer faults (11 in western 
and 12 in eastern Crete) intersect the coastline and their measured lengths are minimums (circles in Fig. 2 \& blue/dark grey outlined symbols in 9f). In many of these cases the position and orientation of the coastline is influenced by footwall uplift and/or hangingwall subsidence (see $A, B, C, D$ and $E$ in Fig. 2a \& b). In most cases the seafloor bathymetry surrounding Crete is not sufficiently well known to map these faults offshore and to estimate their total lengths (Sakellariou et al., 2018). Therefore, earthquake parameters (magnitude, SED and recurrence intervals) calculated for these censored faults are regarded as minimums. Nevertheless, the similarity in the $\mathrm{R}^{2}$ values of the displacement-length relationships for datasets that include and exclude the faults that intersect the coastline (Fig. 9f) indicate that coastal censoring does not impact our first-order conclusions on paleoearthquakes and long-term accumulation of fault slip during earthquakes.

\section{Earthquake parameters}

Cosmogenic dating $\left({ }^{36} \mathrm{Cl}\right)$ of limestone fault scarps in mainland Greece and Italy indicate that they typically form due to slip in $<10$ earthquakes with co-seismic throws of up to $2 \mathrm{~m}$ (e.g. Benedetti et al., 2003, 2013, Mechernich et al., 2018) (e.g., Fig. 1). Similar data are available for the Spili Fault in Crete where Mouslopoulou et al. (2014) identified five events since 16.5 ka, with single event displacements (SED) of 1-2.5 m (average $1.8 \mathrm{~m}$ ) and recurrence intervals of 800-9000 years (average $3300 \mathrm{yrs}$ ). Direct information on the timing and size of paleoearthquakes is rare for active faults on Crete and cosmogenic dating of all active-fault scarps identified in this study impractical. For the purposes of this study we calculate average maximum SED and recurrence intervals for all faults in the database using the maximum postglacial scarp height, the topographic fault length and the SED-Length relationship derived for normal faults by Wesnousky (2008) for historical earthquakes (i.e. Max SED $(m)=0.09 *$ 
Length $(\mathrm{km})$ ). For example, the Spili Fault with a post-glacial scarp height of $9 \pm 0.2 \mathrm{~m}$, a scarp age of $16.5 \pm 0.5 \mathrm{ka}$ and a topographic fault length of $\sim 20 \pm 0.5 \mathrm{~km}$, would require five events with an average maximum SED of $1.8 \pm 0.05 \mathrm{~m}$ and an average recurrence interval of $3.3 \pm 0.4$ kyr. These values are comparable to the earthquake parameters derived using ${ }^{36} \mathrm{Cl}$ analysis by Mouslopoulou et al. (2014), which supports the approach employed to estimate these averages, although due to the sampling issues (discussed below) we regard all earthquake parameters presented here to be first-order only.

A number of sampling deficiencies likely apply to the data used in this study to calculate earthquake parameters. Incomplete sampling of post-glacial >Mw6 earthquakes is probable on Crete (as it is in all areas of active faulting), because some events may not rupture the ground surface or because surface erosion or deposition processes are sufficiently high to remove or conceal evidence of surface-rupturing earthquakes (e.g., McCalpin, 2009; Hecker et al., 2013; Nicol et al., 2016a). This potential incompleteness could have a number of consequences for the population of surface-rupturing earthquakes derived from the postglacial fault scarps. First, because some events on each fault may be sub-resolution, the geological sample should be regarded as defining the maximum average recurrence interval and SED (i.e. resolving more events would reduce the recurrence interval and the unsampled earthquakes are likely to have relatively small SED). A second consequence of this incompleteness is that the number of active faults and potential earthquake sources may be under estimated for the region of Crete, leading to under-estimates in the total number of surface-rupturing events during the post-glacial period.

\section{Relationships between fault displacements and lengths}


Analysis of fault displacement and length data provides a basis for improved understanding of individual earthquakes and how these events accrue on faults over timescales of thousands to millions of years. We examine faulting due to accumulation of earthquake slip using plots of displacement-length (D-L) and displacement rate-length (DR-L) for post-glacial fault scarps and Quaternary datasets for Crete (Figs 9, $10 \& 11$ ). Similar log-log plots have been widely presented in the literature for inactive fault systems and universally show positive relationships between fault displacements/displacement rates and length (Walsh and Watterson, 1988; Bilham and Bodin, 1992; Cowie and Scholz, 1992; Schlische et al., 1996; Kim and Sanderson, 2005; Mouslopoulou et al., 2009; Nicol et al., 2010). For D-L plots, the vertical position of the data and slope of the line of best-fit can vary between fault systems and for different time intervals in the same system, with the slope generally ranging from 0.5 to 1.5 (Schlishe et al., 1996; Walsh et al., 2002; Kim and Sanderson, 2005; Nicol et al., 2010). These changes in D-L relations may be dependent on a range of factors including, sampling bias, the mechanical properties of the faulted rock, the strain (and number of earthquakes) accommodated by the fault system, the age of the faulted horizons and the degree of fault interaction (Watterson et al., 1996; Bailey et al., 2005; Mouslopoulou et al., 2009; Nicol et al., 2010, 2020; Rotevatn et al., 2019).

To examine the accumulation of earthquake slip of normal faults on Crete we have generated D-L plots for post-glacial $(<\sim 16.5 \pm 2 \mathrm{ka})$ scarps and Quaternary topographic data, along with global compilations for ancient faults (Kim and Sanderson, 2005; Nicol et al., 2016c) and historical normal fault earthquakes (Wesnousky, 2008) (Figs 9 \& 10). The Quaternary data show a strong positive relationship with a slope of $\sim 1.4\left(R^{2}=0.58\right.$, Figs $9 c, 9 d$ \& 10) and plot in a comparable part of the graph to the global dataset for inactive faults (Fig. 10) derived from many publications (e.g., Walsh and Watterson, 1988; Cowie and Scholz, 
1992; Schlishe et al., 1996; Kim and Sanderson, 2005; Bailey et al., 2005; Nicol et al., 2010, 2016c). The slope of the best-fit line for Quaternary data (Fig. 9c \& 9d) is greater than the 0.4 slope for the post-glacial scarps and $\sim 0.3$ slope for the global compilation of normal fault earthquakes (Fig. 10), with values for post-glacial scarps being more scattered than the Quaternary data ( $R^{2}$ values of 0.18 vs 0.58 ) (Figs $9 d \& 10$ ). The greater scatter of post-glacial D-L observations (compared to the Quaternary data) is consistent with active fault studies globally for which the increased scatter has been interpreted to partly arise due to short-term ( $\leq 18 \mathrm{kyr}$ ) changes in displacement rates (Mouslopoulou et al., 2009; Nicol et al., 2009). These rate changes are often interpreted in the literature to reflect temporal fluctuations in earthquake recurrence intervals and SED, with displacement rates varying by up to three orders of magnitude for the same fault depending on the duration of the sample interval (Mouslopoulou et al., 2009). Short-term displacement rate variations typically occur on timescales of 5-10 times the average recurrence interval of the fault (Mouslopoulou et al., 2009). Therefore, estimates of displacement rate for the $\sim 16.5$ kyr post-glacial period would only be expected to be similar to Quaternary displacement rates when their average recurrence intervals are $\sim 3$ kyr or less (see Fig. 12a and "Temporal patterns of active faulting" section for further discussion).

A D-L slope of $>1$ for the Quaternary data requires that average displacement gradients (and the ratio of $D$ to $L$ ) are higher on larger faults than smaller faults. These higher gradients could arise for a number of reasons including: 1) most of the larger faults sampled $(>80 \%)$ intersect or interact with nearby faults and their lengths (and propagation) are restricted; 2) preferential linkage of smaller faults or fault segments that promotes long fault lengths at small displacements (e.g., Cartwright et al., 1995; McLeod et al., 2000); 3) preferential death or temporary abandonment of the smaller faults (e.g., $<10 \mathrm{~km}$ ), and/or; 4) fault development 
primarily achieved by increasing displacements with little increase in length (e.g., Morley, 1999; Walsh et al., 2002; Schlagenhauf et al., 2008, Nicol et al., 2016c, 2020; Rotevatn et al., 2019). The preferential death of smaller faults on geological timescales is an established feature of many ancient fault systems and, for those faults characterised by rapid early propagation (perhaps in some cases facilitated by segment linkage) followed by prolonged displacement accumulation with little or no change in fault length (i.e. the constant length coherent fault growth model: Morley, 1999; Walsh et al. 2002; Nicol et al., 2016c, 2020; Rotevatn et al., 2019), will inevitably lead to a progressive increase in D-L slope as earthquakes accrue greater displacement on fault surfaces.

Direct evidence for the constant length coherent fault growth model is most often provided by seismic reflection lines (Walsh et al., 2002; Childs et al., 2003; Mouslopoulou et al., 2012) and from analogue models (Schlagenhauf et al., 2008), where increments of displacement mapped using time-lapse techniques and growth strata indicate stationary fault tips. There are no such data available for the present study, however, if the faults in Crete were propagating their maximum lengths would have been reached in the post-glacial time interval. Instead, post-glacial lengths on Crete are mostly shorter than their topographic lengths (Figure 5e), and provide no evidence for fault propagation over the last 14-18 ka. The absence of such evidence is a common feature of active faults globally (Mouslopoulou et al., 2012) and probably at least partly reflects our inability to sample low displacements (e.g., on Crete $<3 \mathrm{~m}$ ) approaching rupture tips for paleoseismic events. In addition, we propose that the lengths and geometries of active faults on Crete may not have changed significantly in the Late Quaternary. Similarly static fault geometries are implicit in many earthquake simulations (e.g., Robinson et al., 2009; Richards-Dinger and Dieterich, 2012) and our data 
support the view that output from these models may have value in understanding the longterm (>10 kyr) earthquake behaviour of fault systems.

\section{Temporal patterns of active faulting}

Fault displacement rates for the post-glacial and Quaternary time intervals (Figure 11a \& b) provide information about paleoearthquake processes on active faults in Crete. Displacement rates vary from 0.09-1.2 mm/yr for post-glacial and 0.0025-0.7 mm/yr for Quaternary time intervals, with individual faults accommodating post-glacial displacement rates up to $>10$ times faster than their Quaternary (million-year) rates (Fig. 11c), as it is commonly observed in global fault datasets (Mouslopoulou et al., 2009). The lower bound of the post-glacial dataset is defined by the estimated $\sim 3 \mathrm{~m}$ threshold of the completeness for the displacement measurements (with displacement rates of $\leq \sim 0.2 \mathrm{~mm} / \mathrm{yr}$ ), below which the number of observations decreases and we infer that not all faults have been sampled (see horizontal line on Fig. 11a). The incompleteness of faults with $<\sim 3 \mathrm{~m}$ displacement contributes to the absence of a clear positive relationship between displacement rates and fault length for the post-glacial period. By contrast, for the Quaternary sample interval larger faults on Crete tend to have higher displacement rates (Fig. 11b). The dependence between displacement rate and fault size arises because longer faults have both shorter recurrence intervals (as indicated by the $>1$ slope of data in Figure $11 b$ and shown in Figure 12a) and higher SED (e.g, Wells and Coppersmith, 1994; Wesnousky, 2008). The general positive relationship between displacement rate and fault length has been observed for extensional fault systems globally and leads to the conclusion that larger faults reach their size partly because they are moving faster than small faults in the system (Nicol et al., 1997; Mouslopoulou et al., 2009). One possible explanation for the higher Quaternary displacement rates on longer faults is that 
these lengths were established in the early stages of faulting (as would be suggested by the constant length coherent growth model proposed by Walsh et al., 2002), with higher stresses on longer faults resulting in more slip and higher displacement rates; support for a positive relationship between fracture dimension and stress concentration has been long established in the material science literature (e.g., Gordon, 1978).

We do not believe that the differences in displacement rates on individual faults for the two sample periods can be entirely accounted for by errors in our estimates of the durations of post-glacial and Quaternary faulting or by uncertainties in the measured displacements (Fig. 11). Instead, we suggest that the observed displacement rate variability in part reflects geological processes. One potential interpretation of the available data is that displacement rates have recently increased on the normal faults of Crete, perhaps due to a recent ( $<18 \mathrm{kyr}$ ) change in the rate of slab rollback along the Hellenic margin or to climatic conditions leading to reductions in the effective normal stress on normal faults (e.g., Hetzel and Hampel, 2005). However, sea level and effective normal stresses on normal faults have been rising in the post-glacial period for the eastern Mediterranean Sea (Antonioli et al., 2007; Mouslopoulou et al., 2015b, 2016), while there are no data to support a post-18 kyr increase in the rates of plate-boundary processes along the Hellenic margin (van Hinsbergen and Schmid, 2012). Alternatively, and perhaps more likely, it is possible that this apparent acceleration in displacement rates reflects variable earthquake recurrence intervals and SEDs on individual faults, with sampled faults tending to have been the most seismically active structures during the post-glacial interval. This hypothesis has been previously advanced by Nicol et al. (2009), and is the earthquake equivalent of the 'Sadler Effect' (Sadler, 1981), which has been widely reported for sedimentary systems. These variations in displacement rates are thought to partly reflect temporal variations in SED and 'clustering' of earthquakes (e.g., Marco et al., 
1996), where recurrence intervals and SED can vary by up to an order of magnitude (Mouslopoulou et al., 2009; Nicol et al., 2009). For example, the Spili fault on Crete has a length of $20 \mathrm{~km}$, an average Quaternary displacement rate of $0.4 \mathrm{~mm} / \mathrm{yr}$ and an average recurrence interval of $3.3 \mathrm{kyr}$, variations in recurrence interval from $0.8-9 \mathrm{kyr}$ and in displacement rates from 0.1 to $1.2 \mathrm{~mm} / \mathrm{yr}$ (Mouslopoulou et al., 2014). Here, we refer to variations in earthquake recurrence as 'clustering', which suggests that the recurrence intervals are bimodal, however, it is also possible that the recurrence intervals are defined by log-normal distributions (Nicol et al., 2016b). For such log-normal distributions, the 'clusters' would mainly contain events close to the mode with recurrence intervals less than the mean that are separated by long recurrence events in the tail of the distribution.

Temporal changes in displacement rates on individual active faults may provide information about earthquake processes. Comparison of displacement rates on individual faults for post-glacial and Quaternary time intervals suggests that the rates are most similar for the largest faults in the Crete system (Fig. 11c). One possible explanation for the comparable displacement rates on the largest faults on Crete is that the duration of the postglacial time interval (i.e. $\sim 16.5 \mathrm{kyr}$ ) is sufficiently long to capture multiple events and the range of displacement rate variability on these faults (Mouslopoulou et al., 2009; Relationships between fault displacements and lengths section). By contrast, average recurrence intervals for shorter faults (e.g., $<5 \mathrm{~km}$ ) derived for Quaternary data are typically 10 s of kyr (Fig. 11b \& Fig. 12a) and, except in rare circumstances, too infrequent to be recorded as post-glacial scarps (e.g., they are mostly absent from Figure 11a, plotting below the horizontal line). Therefore, the post-glacial dataset only captures high displacement rate and low recurrence interval component of the surface-rupturing earthquake population. An important consequence of this sampling bias is that for all post-glacial data the average (geometric 
mean) recurrence interval is $2.5 \mathrm{kyr}$ (see dashed line in Fig. 12a) and approximately a factor of four lower than the 11 kyr average recurrence (see black dashed line in Fig. 12a) estimated for the Quaternary. We consider the Quaternary value to be representative of the Crete fault system and note that this average recurrence ( $11 \mathrm{kyr}$ ) is similar to those of extensional fault systems globally, which indicate that the average earthquake recurrence interval for a fault system is likely inversely related to regional strain rates (Fig. 12b) (Mouslopoulou et al., 2009).

\section{Spatial patterns of active faulting}

The orientations of active normal faults on Crete change from north to south, while the densities of these faults vary from east to west along the island (Fig. 2). Approximately eastwest striking faults are primarily confined to southern Crete, with northerly striking faults dominating northern parts of the island (Fig. 2). East-west striking faults $(\mathrm{N}=22)$ are less common than northerly striking faults ( $N=62)$ (Fig. 5a and Fig. S1). The larger east-west faults extend offshore and likely disrupt the seabed (Fig. 2), although these offshore faults are not incorporated into our sample. Both sets of faults have been active during the post-glacial period (Fig. 6) and each accommodates dip-slip normal displacement (Caputo et al., 2010; Mason et al., 2016; Veliz et al., 2018), suggesting that Crete accommodated extension simultaneously in two directions during the last $2 \mathrm{Myr}$ and that this extension is ongoing. Onshore, the east-west faults are characterised by approximately equal numbers of Quaternary only (green lines, Fig. 2) and Quaternary plus post-glacial scarps (red lines, Fig. 2). By contrast, more northerly striking faults predominately have Quaternary plus post-glacial scarps (41 vs 23), from which we conclude that onshore northerly striking faults have been more active and accommodated a greater number of surface-rupturing earthquakes during the post-glacial interval. These suggestions are consistent with GPS data which indicate that 
upper plate extension in Crete is predominately east-west, with relatively minor north-south extension along the south coast (e.g., Floyd et al., 2010). Variability in the faulting patterns across Crete (e.g. from south to north) may be produced by slab roll-back along the curved Hellenic subduction margin; further analysis is, however, required for this hypothesis to be tested.

The numbers of active faults and their post-glacial fault displacements change from west to east along Crete. Faults with post-glacial scarps are approximately three times as abundant in eastern Crete $(n=34)$ than in western parts of the island $(n=10)$ (Figure 2, Fig. 9a, b \& e). In addition, faults active in the post-glacial period appear to have larger displacements for a given fault length in the east compared to the west (Fig. 9a). These data suggest that active faults are more common, have higher displacement rates (for a given fault length) and, on a regional scale, generated more earthquakes (see Implications for seismic hazard section for more discussion) in eastern Crete than in western parts of the island (Fig. 9a, b \& e). A component of this spatial disparity could arise because the White Mountains constitute $25 \%$ of western Crete (Fig. $2 b$ \& c), and few active faults were recorded in the mountainous terrain, perhaps because of the high rates of surface processes or the steep topography. However, there is also a general paucity of active faults in western Crete outside the White Mountains (compared to eastern Crete), suggesting that geodynamic factors may contribute to the change in density of normal faulting from west to east across the island. Support for a geodynamic origin of the spatial variability of active faulting is provided by the historical and instrumental seismicity on Crete (Fig. 13). Shallow (<20 km depth) crustal earthquakes of $\geq M 4$ recorded instrumentally (1964-2017) and events of $\geq \mathrm{M} 6$ onshore Crete in the last 2000 years, are both more common in eastern Crete than western Crete (Fig. 13). Similarly, basin and 
range topography formed in response to normal fault displacements is predominately observed in eastern Crete.

Changes in the numbers and rates of normal faulting from west to east across Crete are consistent with the results of earthquake, geodetic and tectonic uplift studies that indicate temporally transient and spatially variable deformation in the crust beneath Crete (Meulenkamp et al., 1994; Meier et al., 2004; Reilinger et al., 2006; Shaw et al., 2010; Floyd et al., 2010; Mouslopoulou et al., 2015a, b; Saltogianni et al., in review). The seismicity rates (1964-2014) in the Crete region increase significantly eastwards, with most earthquakes in the east rupturing the upper $20 \mathrm{~km}$ of the crust (Meier et al., 2004; Bocchini et al., 2018). Lateral variability in the locus and rates of seismicity is consistent with contemporaneous GPS measurements that indicate margin-normal contraction in western Crete (revealing some strain accumulation on the subduction thrust, a process that is often accompanied by a paucity in background seismicity; Kanamori, 1981), and margin-parallel extension in eastern Crete (Reilinger et al., 2006; Floyd et al., 2010; Saltogianni et al., in review). These changes in deformation styles may partly reflect the westward shallowing (by c. $>10^{\circ}$ ) of the subduction thrust beneath Crete and the eastward increase in the rate of slab roll-back (Meier et al., 2004, 2006; Sodoudi et al., 2006; van Hinsbergen and Schmid, 2012; Jolivet et al., 2013; Bocchini et al., 2018). Faster trench retreat along the eastern segment of the Hellenic margin compared to the western is supported by GPS data (Reilinger et al., 2006). Along-strike variations in the kinematics of Crete are reflected in the landscape, with the White Mountains rising to an altitude of $>2.5 \mathrm{~km}$ in western Crete and eastern Crete being characterised by distinctive basin and range topography controlled by active normal fault displacements.

\section{Discussion}


The present active-fault analysis does not provide direct information about the timing and size of individual paleoearthquakes on Crete, however, it does afford indirect estimates of the magnitudes, locations and numbers of events generated on active normal faults that ruptured the ground surface in the post-glacial time interval. To do this we have calculated the number of paleo-events using the topographic fault lengths and the SED-length equation of Wesnousky (2008) $(\mathrm{Mw}=6.12+0.47 * \log ($ Length) $)$. The calculated number of surface-rupturing earthquakes for each active fault since $16.5 \pm 2$ ka ranges from 1 to 21 with a total $~ 371$ events (66 events in western Crete and 305 in the east) ranging in magnitude from Mw 6.1 to 6.9 (assuming that all faults rupture their entire length in each event), for all 44 faults with mapped post-glacial scarps (Fig. 2). The largest earthquake magnitude estimated from the paleoearthquake record (i.e. Mw 6.9) is comparable to that observed in the historic and instrumental records for Crete (Mw 6.9; Papadopoulos, 2011). To estimate the maximum number of possible surface-rupturing events for the mapped faults, we assume that all Quaternary faults were active during the post-glacial period and used the calculated SED, total displacement and duration of faulting to estimate how many events could have occurred on these faults in the last $16.5 \pm 2 \mathrm{kyr}$. The calculations suggest a further 90 events, bringing the total number to $\sim 450$ in $\sim 16.5 \mathrm{kyr}$ or an average of one large-magnitude (>Mw6) earthquake approximately every 37 yrs.

Comparison of the paleoseismic record with historical events provides a basis for assessing the possible impact of incompleteness and multi-fault ruptures (or triggered slip) on the rate of post-glacial surface-rupturing earthquakes (i.e. >Mw6). Papadopoulos (2011) compiled earthquake information for the last 2000 yrs on Crete, however, these data appear to be incomplete for events >Mw6 (particularly prior to the last 500 years), while many historical earthquakes have uncertain locations and/or magnitudes. Despite these 
uncertainties there have been no known surface ruptures on Crete for at least the last 100 years (Papadopoulos, 2011) and the number of events inferred from the paleoseismic record appears be at least a factor of three higher than observed from the recent historical record. This mismatch may indicate that the last 100 years spanned a seismically quiet period which is not representative of the post-glacial sample interval. Alternatively, we may have overestimated the number of surface-rupturing earthquakes from the paleoseismic record, either because the fault-rupture lengths are too short (leading to a decrease in the SED and recurrence intervals), because some surface-rupturing earthquakes produced slip on more than one fault leading to double counting of events in the paleoseismic record or because the historical data provide an incomplete record of triggered events that might be considered part of an aftershock sequence. Historical events that rupture multiple faults have been observed internationally (e.g., Beanland et al., 1989; Kurushin et al., 1997; Hamling et al., 2017; Mouslopoulou et al., 2019). Such multi-fault ruptures are most likely to occur where the faults are closely spaced (e.g., separation $<5 \mathrm{~km}$ ) or intersect one another, such as occurs at the junction of the Kastelli, Geraki and Nipiditos faults in eastern Crete (Fig. 6), in the southern Messara Basin (Fig. 4b), and along the Western (Fig. 4a) and Eastern (Veliz et al., 2018) Mirabello fault systems in eastern Crete (Fig. 2a). Lastly, it is possible that some historical earthquakes on Crete ruptured multiple faults in a single earthquake sequence (i.e. over time periods hours to months), such as occurred in the Mw 6.71981 Gulf of Corinth event in mainland Greece (Jackson et al., 1982; Mechernich et al., 2018), and only the largest of these events were recorded in the historical record. Independent of whether multi-fault ruptures or triggered slip events are common on Crete, it is likely that most ( $80 \%)$ of the future normal fault earthquakes will occur in eastern Crete, and pose an important seismic hazard. 


\section{Conclusions}

Active normal faults on the eastern Mediterranean island of Crete form prominent limestone scarps of post-glacial age $(16.5 \pm 2 \mathrm{kyr})$ together with basin and range topography, which provides a proxy for vertical displacements since the onset of extension in the Quaternary ( 2 Ma). The sampled faults mainly strike E-ESE and N-NNE in southern and northern Crete, respectively, with northerly striking faults being most common. The active faults are subject to sampling biases including, sub-resolution displacements, fault censoring at the coast and preferential sampling of faults with the highest post-glacial displacement rates, which can lead to undetected active faults and to under estimates of fault lengths. The available data indicates no fault propagation and, for the Quaternary, higher displacement rates on longer faults, supporting a model in which fault lengths and maximum earthquake magnitudes were established early in the development of the fault system. Post-glacial displacement rates (0.09-1.2 mm/yr) are generally higher than Quaternary rates $(0.002-0.7 \mathrm{~mm} / \mathrm{yr})$. We believe that differences in displacement rates between sample intervals arise in part due to 'clustering' of >Mw6 earthquakes on timescales of tens of thousands of years, and preferential sampling of the most seismically active faults in the post-glacial era. Displacement rates for the two sample intervals converge for longer faults because the 16.5 kyr duration of the sample interval is approaching the length scale of displacement-rate variations arising from earthquake 'clustering'. Earthquakes on normal faults are most likely to occur in eastern Crete where the greatest numbers of active faults were recorded and surface deformation is primarily controlled by slab rollback processes. Paleoarthquakes $>\mathrm{Mw}$ 6 on Crete are about a factor of three more frequent than historical events for the last 100 
yrs, which could be partly due to ruptures of multiple faults during individual paleoearthquakes or to unrecognised triggered slip events in the historical record.

\section{Acknowledgements}

We thank the Greek Cadastre for providing the high-resolution DEM of Crete. Violeta Veliz is thanked for help with earlier versions of figures 2, 4 and 6. We acknowledge Gian Maria Bocchini (Ruhr University of Bochum) and Vasso Saltogianni (GFZ-Postdam) for discussions on the kinematics of the Hellenic subduction and Charalambos Fassoulas for discussions on the Idaion Fault. Thank you to journal reviewers Amotz Agnon and two further anonymous reviewers for helping to improve the clarity of the manuscript.

\section{References}

Angelier, J., N. Lyberis, X. Le Pinchon, E. Barrier, and P. Huchon (1982). The tectonic development of the Hellenic arc and the Sea of Crete: a synthesis, Tectonophysics 86, 159196.

Antonioli, F., M. Anzidei, K. Lambeck, R. Auriemma, D. Gaddi, S. Furlani, P. Orrù, E. Solinas, A. Gaspari, S. Karinja, V. Kovačić, L. Surace (2007). Sea-level change during the Holocene in Sardinia and in the northeastern Adriatic (central Mediterranean Sea) from archaeological and geomorphological data, Quat. Sci. Rev. 26, 2463-2486.

Bailey, W.R., J.J. Walsh, T. Manzocchi (2005). Fault populations, strain distribution and basement reactivation in the East Pennines Coalfield, U.K, J. Struct. Geol. 27, 913-928.

Becker, D., T., Meier, M. Bohnhoff, H.P. Harjes (2010). Seismicity at the convergent plate boundary offshore Crete, Greece, observed by an amphibian network, J. Seismol. 14, 369392.

Beanland, S., K. R. Berryman, and G. H. Blick (1989). Geological invesitgations of the 1987 Edgecumbe earthquake, New Zealand, New Zeal. J. Geol. Geophys. 32, 73-91.

Benedetti, L., R. Finkel, G. King, R. Armijo, D. Papanastasiou, F.J. Ryerson, F. Flerit, D. Farber, and G. Stavrakakis (2003). Motion on the Kaparelli fault (Greece) prior to the 1981 earthquake sequence determined from ${ }^{36} \mathrm{Cl}$ cosmogenic dating, Terra Nova 15, 118-124. 
Benedetti L., I., Manighetti, Y., Gaudemer, R., Finkel, J., Malavieille, K., Pou, M., Arnold, G., Aumaître, D., Bourlès, and K. Keddadouche (2013). More than 30 large earthquakes broke the Fucino faults (Central Italy) in synchrony in the last $12 \mathrm{ka}$, as revealed from in situ $36 \mathrm{Cl}$ exposure dating, J. Geophys. Res. 118, 4948-4974.

Biasi, G.P., and S.G. Wesnousky (2017). Bends and Ends of Surface Ruptures, Bull. Seismol. Soc. Am. 107, 2543-2560.

Bilham, R., and P. Bodin (1992). Fault Zone Connectivity: Slip Rates on Faults in the San Francisco Bay Area, California, Science 258, 281-284.

Bocchini G. M., A., Brüstle, D., Becker, T., Meier, P.E., van Keken, M., Ruscic, G.A., Papadopoulos, M., Rische, and W. Friederich (2018). Tearing, segmentation and backstepping of subduction in the Aegean: new insights from seismicity, Tectonophysics 734-735, 96-118.

Caputo, R., C. Monaco, and L. Tortorici (2006). Multiseismic cycle deformation rates from Holocene normal fault scarps on Crete (Greece), Terra Nova 18, 181-190.

Caputo, R., S., Catalano, C., Monaco, R., Romagnoli, G., Tortorici, and L. Tortorici (2010). Active faulting on the island of Crete (Greece), Geophys. J. Int. 183, 111-126.

Cartwright, J. A., Trudgill, B., and C.S. Mansfield (1995). Fault growth by segment linkage: an explanation for scatter in maximum displacement and trace length data from the Canyonlands Grabens of S.E. Utah, J. Struct. Geol. 17, 1319-1326.

Childs, C., A., Nicol, J., Walsh, and J. Watterson (2003). The growth and propagation of synsedimentary faults, J. Struct. Geol. 25, 633-648.

Cowie, P.A., and C.H. Scholz (1992). Physical explanation for the displacement-length relationship of faults using a post-yield fracture mechanics model, J. Struct. Geol. 14, 11331148.

Doutsos, T., and G. Poulimenos (1992). Geometry and kinematics of active faults and their seismotectonic significance in the western Corinth-Patras rift (Greece). J. Struct. Geol. 14, 689-699.

Fassoulas, C. (1999). The structural evolution of central Crete: insight to the tectonic evolution of the South Aegean (Greece), J. Geodyn. 27, 23-43.

Fassoulas, C. (2001). The tectonic development of a Neogene basin at the leading edge of the active European margin: the Heraklion basin, Crete, Greece, J. Geodyn. 31, 49-70.

Fassoulas, C, and M. Nikolakakis (2005). Landscape response to the tectonic uplift of Crete, Greece. Bull. Geol. Soc. Greece XXXVII, 201-217. 
Floyd, M. A., et al. (2010). A new velocity field for Greece: Implications for the kinematics and dynamics of the Aegean, J. Geophys. Res. 115, B10403, doi:10.1029/2009JB007040.

Friedrich, A.M., J., Lee, B.J., Wernicke, K., Sieh (2004). Geologic context of geodetic data across a Basin and Range normal fault, Crescent Valley, Nevada. Tectonics 23, TC2015, https://doi.org/10.1029/2003TC001528

Gallen, S.F., K.W., Wegmann, D., Bohnenstiehl, F.J., Pazzaglia, M.T., Brandon, and C. Fassoulas (2014). Active Simultaneous Uplift and Margin-Normal Extension in a Forearc High, Crete, Greece, Earth Planet. Sci. Lett. 398, 11-24.

Ganas, A., C., Fassoulas, A., Moschou, G., Bozionelos, G., Papathanassiou, C., Tsimi, S., Valkaniotis (2018). Geological and seismological evidence for NW-SE crustal extension at the southern margin of Heraklion basin, Crete. Bull. Geol. Soc. Greece 51, 52-75.

Gawthorpe, R.L., M.R., Leeder, H., Kranis, E., Skourtsos, J.E., Andrews, G.A., Henstra, G.H., Mack, M., Muravchik, J.A., Turner, and M. Stamatakis (2018). Tectono-sedimentary evolution of the plio-pleistocene Corinth rift, Greece, Basin Res. 30, 448-479, 10.1111/bre.12260.

Gilbert, G.K. (1884). A theory of earthquakes of the Great Basin, with practical application (from the Salt Lake Tribune of September 30, 1883), Am. J. Sci. 27, 49-53.

Gordon, J.E. (1978). Structures, or why things don't fall down, Plenum, New York.

Hamling, I.J., S., Hreinsdóttir, K., Clark, J., Elliott, C., Liang, E., Fielding, N., Litchfield, P., Villamor, L., Wallace, T.J., Wright, et al. (2017). Complex multifault rupture during the 2016 Mw 7.8 Kaikōura earthquake, New Zealand, Science 365, doi: 10.1126/science.aam7194.

Hecker, S., N.A., Abrahamson, and K.E. Wooddell (2013). Variability of displacement at a point: implications for earthquake-size distribution and rupture hazard on faults, Bull. Seis. Soc. Am. 103, 651-674, doi: 10.1785/0120120159.

Hetzel, R., and A. Hampel (2005). Slip rate variations on normal faults during glacialinterglacial changes in surface loads, Nature 435, 81-84.

Hughes, P.D., J.C., Woodward, and P.L. Gibbard (2006). Quaternary glacial history of the Mediterranean mountains. Progr. Phys. Geo. 30, 334-364

Jackson, J.A., J., Gagnepain, G., Houseman, G.C.P., King, P., Papadimitriou, C., Soufleris, and J. Virieux (1982). Seismicity, normal faulting, and the geomorphologicadl evelopmento $f$ the Gulf of Corinth: The Corinth earthquakes of February and March 1981, Earth Planet. Sci. Lett. 57, 377-397.

Jolivet, L., et. al. (2013). Aegean tectonics: strain localisation, slab tearing and trench retreat, Tectonophysics 597, 1-33. 
Jusseret, S., and M. Sintubin (2012). All that rubble leads to trouble: reassessing the seismological value of archaeological destruction layers in Minoan Crete and beyond, Seismol. Res. Lett. 83, 736-742.

Jusseret, S., C., Langohr, and M. Sintubin (2013). Tracking earthquake archaeological evidence in Late Minoan IIB (c. 1300-1200 BC) Crete (Greece): a proof of concept, Bull. Seismol. Soc. Am. 103, 3026-3043; doi:10.1785/0120130070.

Kanamori, H. (1981). The nature of seismicity patterns before large earthquakes. anamori, $\mathrm{H}$. (1981) In: Simpson, D.W. and Richards, P.G., Eds., Earthquake Prediction, Am. Geophys. Un., Washington, 1-19.

Kim, Y., and D. Sanderson (2005). The relationship between displacement and length of Faults, Earth-Sci. Rev. 68, 317-334.

Kiratzi, A., and E. Louvari (2003). Focal mechanisms of shallow earthquakes in the Aegean Sea and the surrounding lands determined by waveform modeling: a new database. $J$. Geodyn. 36, 251-274.

Kokinou, E., A., Tiago, and E. Kamperis (2012). Structural decoupling in a convergent forearc setting (southern Crete, Eastern Mediterranean), Geol. Soc. Am. Bull. 124, 1352-1364.

Konstantinou, K.I., V., Mouslopoulou, W.-T., Liang, O., Heidbach, O., Oncken, and J. Suppe (2017). Present-day crustal stress field in Greece inferred from regional-scale damped inversion of earthquake focal mechanisms, J. Geophys. Res. 122, 506-523.

Kurushin, R. A., A. Bayasgalan, M. Ölziybat, B. Enkhtuvshin, P. Molnar, C. Bayarsayhan, K. W. Hudnut, and J. Lin (1997). The surface rupture of the 1957 Gobi-Altay, Mongolia, earthquake, Geol. Soc. Am. Spec. Pap. 320, 143 pp.

Manighetti, I., C., Caulet, L., De Barros, C., Perrin, F., Cappa, and Y. Gaudemer (2015). Generic along-strike segmentation of Afar normal faults, East Africa: Implications on fault growth and stress heterogeneity on seismogenic fault planes, Geoch. Geophys. Geosyst. 16, 443-467.

Marco, S., M., Stein, and A. Agnon (1996). Long-term earthquake clustering: A 50,000-year paleoseismic record in the Dead Sea Graben, J. Geophys. Res. 101 B3, 6179-6191.

Mason, J., S., Schneiderwind, A., Pallikarakis, T., Wiatr, S., Mechernich, I., Papanikolaou, and K. Reicherter (2016). Fault structure and deformation rates at the Lastros-Sfaka Graben, Crete, Tectonophysics 683, 216-2321.

McCalpin, J.P. (2009). Paleoseismology, 2nd Edition: International Geophysics Series, Vol. 95, Elsevier Publishing, 1-647. 
McLeod, A.E., N.H., Dawers, and J.R. Underhill (2000). The propagation and linkage of normal faults: insights from the Strathspey-Brent-Statfjord fault array, northern North Sea, Bas. Res. 12, 263-284.

McClusky, S., S., Balassanian, A., Barka, C., Demir, S., Ergintav, I., Georgiev, O., Gurkan, M., Hamburger, K., Hurst, H., Kahle, K., Kastens, et al. (2000). Global Positioning System constraints on plate kinematics and dynamics in the eastern Mediterranean and Caucasus, $J$. Geophys. Res. 105, 5695-5719.

Mechernich, S., S., Schneiderwind, J., Mason, I.D., Papanikolaou, G., Deligiannakis, A., Palikarakis, S.A., Binnie, T.J., Dunai, and K. Reicherter (2018). The Seismic History of the Pisia Fault (Eastern Corinth Rift, Greece) from Fault Plane Weathering Features and Cosmogenic ${ }^{36} \mathrm{Cl}$ Dating, J. Geophys. Res. 123, 4266-4284.

Meier, T., M., Rische, B., Endrun, A., Vafidis, and H.P. Harjes (2004). Seismicity of the Hellenic subduction zone in the area of western and central Crete observed by temporary local seismic networks, Tectonophysics 383, 149-169.

Meulenkamp J.E., G.J., van der Zwaan, and W.A. van Wamel (1994). On late Miocene to recent vertical motions in the Cretan segment of the Hellenic arc, Tectonophysics 234, 53-72.

Mitchell, S.G., A. Matmon, P.R., Bierman, Y., Enzel, M. Caffee, and D. Rizzo (2001). Displacement history of a limestone normal fault scarp, northern Israel, from cosmogenic 36Cl, Journal of Geophysical Research: Solid Earth 106(B3), 4247-4264.

Morley, C.K. (1999). Patterns of displacement along large normal faults; implications for basin evolution and fault propagation, based on examples from East Africa. AAPG Bull. 83, 613-634.

Mountrakis, D., A., Kilias, A., Pavlaki, C., Fassoulas, E., Thomaidou, C., Papazachos, C., Papaioannou, Z., Roumelioti, C., Benetatos, and D. Vamvakaris (2012). Neotectonic study of the Western Crete. Seismic risk evaluation of the active faults, In: (Ed.) E. Skourtsos, and G. Lister, The Geology of Greece, J. Virt. Expl., Electronic Edition, ISSN 1441-8142, 42, paper 4.

Mouslopoulou, V., J.J., Walsh, and A. Nicol (2009). Fault displacement rates over a range of timescales, Earth Planet. Sci. Lett. 278, 186-197.

Mouslopoulou, V., A., Nicol, J.J., Walsh, J.G., Begg, D.B., Townsend, and D.T. Hristopulos (2012). Fault-slip accumulation in an active rift over thousands to millions of years and the importance of paleoearthquake sampling, J. Struct. Geol. 36, 71-80.

Mouslopoulou, V., D., Moraetis, D., L., Benedetti, V., Guillou, O., Bellier, and D. Hristopulos (2014). Normal faulting in the forearc of the Hellenic subduction margin: Paleoearthquake history and kinematics of the Spili Fault, Crete, Greece, J. Struct. Geol. 66, 298-308. 
Mouslopoulou, V., A., Nicol, J., Begg, O., Oncken, and M. Moreno (2015a). Clusters of megaearthquakes on upper plate faults control the Eastern Mediterranean hazard, Geophys. Res. Lett. 42, 10282-10289.

Mouslopoulou, V., J., Begg, A., Nicol, O., Oncken, and C. Prior (2015b). Formation of Late Quaternary paleoshorelines in Crete, Eastern Mediterranean, Earth Planet. Sc. Lett. 431, 294307.

Mouslopoulou, V., O., Oncken, S., Hainzl, and A. Nicol (2016). Uplift rate transients at subduction margins due to earthquake clustering, Tectonics 35, 2370-2384.

Mouslopoulou, V., V., Saltogianni, A., Nicol, O., Oncken, J., Begg, A., Babeyko, S., Cesca, and M. Moreno (2019). Breaking a subduction termination from top to bottom: the large M7.8 Kaikōura Earthquake, Earth Planet. Sci. Lett. 506, 221-230.

Mozafari, N., D., Tikhomirov, Ö., Sumer, Ç., Özkaymak, , B., Uzel, S., Yeşilyurt, S., Ivy-Ochs, C., Vockenhuber, H., Sözbilir and N. Akçar (2019). Dating of active normal fault scarps in the Büyük Menderes Graben (western Anatolia) and its implications for seismic history Quatern. Sci. Rev. 220, 111-123.

Nicol, A., J.J., Walsh, J., Watterson, and J.R., Underhill (1997). Displacement rates of normal faults, Nature 390, 157-159.

Nicol, A., J.J., Walsh, K., Berryman, and S., Nodder (2005). Growth of a normal fault by the accumulation of slip over millions of years, J. Struct. Geol. 27, 327-342.

Nicol, A., Walsh, K., Berryman, and P. Villamor (2006). Interdependence of fault displacement rates and paleoearthquakes in an active rift, Geology 34, 865-868.

Nicol, A., J.J., Walsh, V. Mouslopoulou, and P. Villamor (2009). Earthquake histories and Holocene acceleration of fault displacement rates, Geology 37, 911-914.

Nicol, A., J.J., Walsh, P., Villamor, H., Seebeck, and K.R. Berryman (2010). Normal fault interactions, paleoearthquakes and growth in an active rift, J. Struct. Geol. 32, 1101-1113.

Nicol A., R., Van Dissen, Stirling, and M. Gerstenberger (2016a). Completeness of the paleoseismic active fault record in New Zealand, Seismol. Res. Lett. 86, 1299-1310. doi:10.1785/0220160088.

Nicol, A., R., Robinson, R. Van Dissen, and A. Harvison (2016b). Variability of recurrence interval and single-event slip for surface-rupturing earthquakes in New Zealand, NZ J. Geol. Geophys. 59, 97-116. 
Nicol, A., C., Childs, J.J., Walsh, T., Manzocchi, and M.P.J. Schöpfer (2016c). Interactions and growth of faults in an outcrop-scale system. In: The Geometry and Growth of Normal Faults. (Edited by Childs, C., Holdsworth, R. E., Jackson, C. A.-L., Manzocchi, T., Walsh, J. J. \& Yielding, G.), Geol. Soc. Lond., Sp. Publ. 439, doi.org/10.1144/SP439.9, 2015.

Nicol, A., J.J., Walsh, C., Childs, and T._Manzocchi (2020). The growth of faults (Chapter 6). In: Understanding Faults: Detecting, Dating, and Modelling (Edited by Tanner D. and C. Brandes). Published by Elsevier, pg 221-255.

Papadopoulos, G.A. (2011). A seismic history of Crete: earthquakes and tsunamis 2000 B.C. 2011 A.D. Ocelotos Publ, 415 pp.

Papastamatiou, J., D., Vetoulis, and A. Tataris (1959). Geological Map of Greece, 1:50.000 scale. lerapetra Sheet. Institute for Geology and Subsurface Research (IGME), Greece.

Pierce, K.L., and L.A. Morgan (1992). The track of the Yellowstone hot spot: volcanism, faulting, and uplift. Geol. Soc. Am. Mem. 179, 1-54.

Poulimenos, G. (2000). Scaling properties of normal fault populations in the western Corinth Graben, Greece: implications for fault growth in large strain settings. J. Struct. Geol. 22, 307322.

Reilinger, R., S., McClusky P., Vernant, S., Lawrence, S. Ergintav, Rahsan Cakmak, H., Ozener, F. Kadirov, I., Guliev, R., Stepanyan, et al. (2006). GPS constraints on continental deformation in the Africa-Arabia-Eurasia continental collision zone and implications for the dynamics of plate interactions, J. Geophys. Res. 111, B05411, doi:10.1029/2005JB004051.

Richards-Dinger, K., J.H. Dieterich (2012). RSQSim Earthquake Simulator. Seismological Research Letters 83 (6), 983-990, https://doi.org/10.1785/0220120105

Roberts, G., A.M., Michetti, P., Cowie, N.C., Morewood, and I. Papanikolaou (2002). Fault sliprate variations during crustal-scale strain localisation, central Italy. Geophys. Res. Lett. 29, 10.1029/2001GL013529.

Robinson, R., A. Nicol, J.J. Walsh, P. Villamor (2009). Features of earthquake occurrence in a complex normal fault network: results from a synthetic seismicity model of the Taupo Rift, New Zealand. J. Geophys. Res.114, B12306, doi:10.1029/2008JB006231.

Rotevatn, A., C.A., Jackson, A.B.M., Tvedt, R., Bell, and I. Blækkan (2019). How do normal faults grow? J. Struct. Geol. 125, 174-184. https://doi.org/10.1016/j.jsg.2018.08.005

Sadler, P.M. (1981). Sediment accumulation rates and the completeness of stratigraphic sections, J. Geol. 89, 569-584. 
Sakellariou, D., and Tsampouraki-Kraounaki, K. (2019). "Chapter 14 - plio-quaternary extension and strike-slip tectonics in the aegean," in Transform Plate Boundaries and Fracture Zones, ed. J. C. Duarte (Amsterdam: Elsevier), 339-374. doi: 10.1016/B978-0-12-8120644.00014-1

Saltogianni, V., V., Mouslopoulou, O., Oncken, A., Nicol, M., Gianniou, and S., Mertikas (In review). Elastic fault interactions and earthquake-rupture along the southern Hellenic subduction plate-interface zone in Greece. Geophys. Res. Lett., In review.

Schlagenhauf, A., I., Manighetti, J., Malavieille, and S. Dominguez (2008). Incremental growth of normal faults: insights from a laser-equipped analog experiment. Earth Planet. Sci. Lett. 273, 299-311.

Schlische, R.W., S.S. Young, R.V., Ackermann, and A. Gupta (1996). Geometry and scaling relations of a population of very small rift-related normal faults. Geology 24, 683-686.

Sieh, K. E. (1978). Slip along the San Andreas fault associated with the great 1857 earthquake. Bull. Seismol. Soc. Am. 68, 1421-1448.

Shaw, B., and J. Jackson (2010). Earthquake mechanisms and active tectonics of the Hellenic subduction zone, Geophys. J. Int. 181, 966-984.

Sodoudi, F., R. Kind, D. Hatzfeld, K. Priestley, W. Hanka, K. Wylegalla, G. Stavrakakis, A. Vafidis, H. P. Harjes, and M. Bohnhoff (2006). Lithospheric structure of the Aegean obtained from P and S receiver functions, J. Geophys. Res. 111, B12307.

Stein, R.S., G.C.P., King, and J.B. Rundle (1988). The growth of geological structures by repeated earthquakes 2. Field examples of continental dip slip faults. J. Geophy. Res. 93, 13319-13331.

van Hinsbergen, D.J.J., and S.M. Schmid (2012). Map-view resoration of Aegean-west Anatolian accretion and extension since the Eocene, Tectonics 31, TC5005.

Veliz, V., V., Mouslopoulou, A., Nicol, C., Fassoulas, J., Begg, and O. Oncken (2018). Millenial to million normal-fault interactions on the forearc of a subduction margin, Crete, Greece, J. Struct. Geol. 113, 225-241 https://doi.org/10.1016/j.jsg.2018.05.019.

Wallace, R.E. (1987). Grouping and migration of surface faulting and variations in slip rates on faults in the Great Basin Province, Bull. Seismol. Soc. Am. 77, 868-876.

Walsh, J.J., A., Nicol, and C. Childs (2002). An alternative model for the growth of faults. J. Struct. Geol. 24, 1669-1675.

Watterson, J., J.J., Walsh, P.A., Gillespie, and S. Easton (1996). Scaling systematics of fault sizes on a large scale range fault map. J. Struct. Geol. 18, 199-214. 
Wells, D.L., and K.J. Coppersmith (1994). New empirical relationships among magnitude, rupture length, rupture width, rupture area and surface displacement, Bull. Seismol. Soc. Am. 8, 974-10.

Wesnousky, S.G. (2008). Displacement and geometrical characteristics of earthquake surface ruptures: issues and implications for seismic-hazard analysis and the process of earthquake rupture. Bull. Seismol. Soc. Am. 98, 1609-16332, doi: 10.1785/0120070111. 


\section{Figure captions}

Figure 1 (a) Schematic block diagram showing the range and basin topography and active fault scarp, together with measurements of Quaternary vertical displacement measured from bedrock and range height. (b) Schematic graph showing displacement accumulation on geological (Quaternary) timescales (thick black line) with the open circle showing the cumulative displacement indicated in the block diagram. Thick dashed line shows average displacement accumulation for the duration of faulting at a rate of $0.5 \mathrm{~mm} / \mathrm{yr}$. Displacement curve in the box is shown in ' $c$ '. (c) Schematic graph showing the accumulation of fault displacement (thick black line) in 5 earthquakes (labelled EQ1-5). SED in individual earthquakes is indicated by the height of the vertical sections of the curve, while recurrence intervals are defined by the lengths of the horizontal sections of the curve. Thick dashed line shows average displacement accumulation for the duration of faulting at a rate of $0.5 \mathrm{~mm} / \mathrm{yr}$, while the thick grey line shows the range of displacement rates averaged for two earthquake cycles.

Figure 2 Fault map of eastern (a) and western (b) Crete. Lines on DEM indicate active normal faults with resolvable activity during the last $\sim 16.5$ years (postglacial scarps are also highlighted) and late-Quaternary activity alone (with no resolvable postglacial displacement). Numbers next to faults correspond to fault ID's. Filled circles indicate localities where faults intersect the coastline. The Klima Fault $(I D=24)$ is extended offshore for $\sim 21 \mathrm{~km}$ based on bathymetric data from EMODNET (see Data and Resources). Circle on the Spili Fault (Fault $I D=25$ ) shows the locality where cosmogenic dating constrained the age of the postglacial period on Crete (that is $16.5 \mathrm{Ka}$; Mouslopoulou et al., 2014). The localities of Figures 4 \& 6 and the study area of Veliz et al. (2018) are indicated. WM=White Mountains. c) Crete (indicated by the rectangle) is located on the forearc of the Hellenic subduction margin, along which the African and the Eurasian plates converge. Labelled arrows show geodeticallyderived site velocities (mm/yr) relative to a fixed African plate (Reilinger et al., 2010).

Figure 3: Photographs (a-e) illustrating postglacial fault scarps on Crete. Numbers by fault names correspond to the fault ID. The maximum post-glacial (PG) and Quaternary displacements, together with their uncertainties, are annotated. Circle in (d) highlights a section of the Fournofaraggo Fault $(I D=35)$ scarp that is being locally buried by fan debris 
material. Arrows in (a-d) and (e) indicate postglacial and late-Quaternary fault scarps, respectively.

Figure 4: (a) DEM of the Western Mirabello Fault System (WMFS) in Elounta area with and without the interpreted normal faults. (b) Active normal faulting within the Messara Basin and topographic profiles across faults with Quaternary only $\left(A-A^{\prime}\right)$ and Quaternary plus postglacial (B-B') activity. Numbers next to faults correspond to fault ID's. The sections of the active faults that present post-glacial activity (e.g., fresh scarp face) and only Quaternary activity. For location of the WMFS and the Messara Basin on Crete see Fig. 2b.

Figure 5: Plots showing active fault orientation, displacements and lengths for post-glacial and Quaternary faults. a) Graph of fault dip versus fault strike for fault planes exposed along active fault scarps with post-glacial displacement. b) Frequency histogram of fault dip for data in (a). c) Histogram of fault strike for data in (a). d) Plot of Quaternary fault displacement measured from topography against post-glacial fault displacement measured from active fault scarps. e) Plot of Quaternary fault length determined from topography against postglacial fault length measured from active fault scarps. Post-glacial displacements $<3 \mathrm{~m}$ and trace lengths $<2 \mathrm{~km}$ are inferred to be incomplete (see vertical dashed lines in (d) and (e), respectively.

Figure 6: DEM illustrates active faults of various orientations/sizes intersecting one another at high angles in the region of Kastelli, eastern Crete (see Fig. $2 b$ for locality). All faults across this intersection demonstrate postglacial activity indicating that both sets of faults ( N-S and $\sim E-W)$ were simultaneously active. Displacement profiles (P1-P3) across three of the intersecting faults indicate the relationship between topography and cumulative fault displacement. Numbers by fault names correspond to the fault ID's.

Figure 7: Geological cross-sections across the Ha-Gorge segment of the lerapetra Fault $(I D=71)(a)$ and the Kera Fault $(I D=11)(b)$ in eastern and western Crete, respectively, indicating the relationship between vertical displacement of bedrock and associated topography (modified from Mountrakis et al., 2012 and Mason et al., 2016). Comparison reinforces the 
notion that topography across mountain ranges bounded by faults may be used as a firstorder proxy for long-term fault displacement.

Figure 8: Displacement profiles along the Lastros (a \& b) and Sfaka (c \& d) faults over two distinct time-intervals: 0-2 Ma and 0-16.5 kyr (modified from Veliz et al., 2018).

Figure 9: Plots illustrating D-L relationships for different time-intervals: (a) Post-glacial displacement vs post-glacial fault scarp length, (b) Post-glacial displacement vs topographic fault length, c) Quaternary displacement vs Quaternary topographic fault length, d) Postglacial (red) and Quaternary displacement vs Quaternary topographic fault length, e) Quaternary displacement vs Quaternary topographic fault length, indicating the spatial distribution (east vs west Crete) and the timing of activity (post-glacial scarp vs no post-glacial scarp) on each fault, f) as (e) but also highlighting (with blue/dark grey outline) the faults that intersect the coastline. The best-fit line and $\mathrm{R}^{2}$ values are calculated by excluding (blue/dark grey) and including (black) the faults that intersect the coastline. The similarity in the $\mathrm{R}^{2}$ values for the two datasets imply that the impact of coastal censoring in our analysis is minimum.

Figure 10: Displacement-length data for Quaternary and post-glacial measurements from Crete, global displacement-length data (Nicol et al., 2016b) and single-event displacement rupture lengths for historical earthquakes (Wesnousky, 2008). Each dataset is labelled on the figure (i.e. Blue filled circles historical earthquakes, red filled circles post-glacial scarps, black filled circles Quaternary faults, grey filled circles global dataset for ancient faults). Least squares lines of best fit and $R^{2}$ values are also indicated for each dataset

Figure 11: Plots of post-glacial displacement rate vs topographic fault length (a) and Quaternary (topographic) displacement rate vs topographic fault length (b) for all faults sampled. Black lines show recurrence intervals of $0.1,1,10$ and 100 kyr. Black horizontal line at $0.2 \mathrm{~mm} / \mathrm{yr}$ indicates the resolution threshold of our dataset for post-glacial scarps. Lines of best fit are least squares values. (c) Post-glacial displacement rates vs. Quaternary displacement rates. Black lines show displacement ratios of 10:1 and 1:1 and 1:10. 
Figure 12: (a) Plot illustrating the average recurrence intervals on individual normal faults on Crete over two sample periods (postglacial and Quaternary). The lower and upper horizontal dashed lines represent the geometric mean of the recurrence interval for the postglacial ( 2.5 kyr) and Quaternary ( 11 kyr) datasets, respectively. (b) Plot illustrating the inverse relationship between average recurrence interval and regional strain rate. Note that Crete follows the trend defined by the global dataset (for references associated with this dataset see Mouslopoulou et al., 2009). BR=Basin and Range (USA), Cr=Crete (Greece), Tar=Taranaki Rift (New Zealand), SW=South Wanganui Basin (New Zealand), Ap=Apennines (Italy), Ta=Taupo Rift (New Zealand), Co=Corinth Rift (Greece).

Figure 13: Map showing active fault traces for Crete along with the locations of shallow $(<\sim 20$ $\mathrm{km}$ ) historical (0-2000 years B.P.) and shallow $(<\sim 20 \mathrm{~km})$ instrumental (1964-2017) seismicity data. Yellow (grey in in greyscale version of the figure) epicentres represent the only two $M>6$ earthquakes that occurred onshore Crete between 2000 and 500 years B.P. 

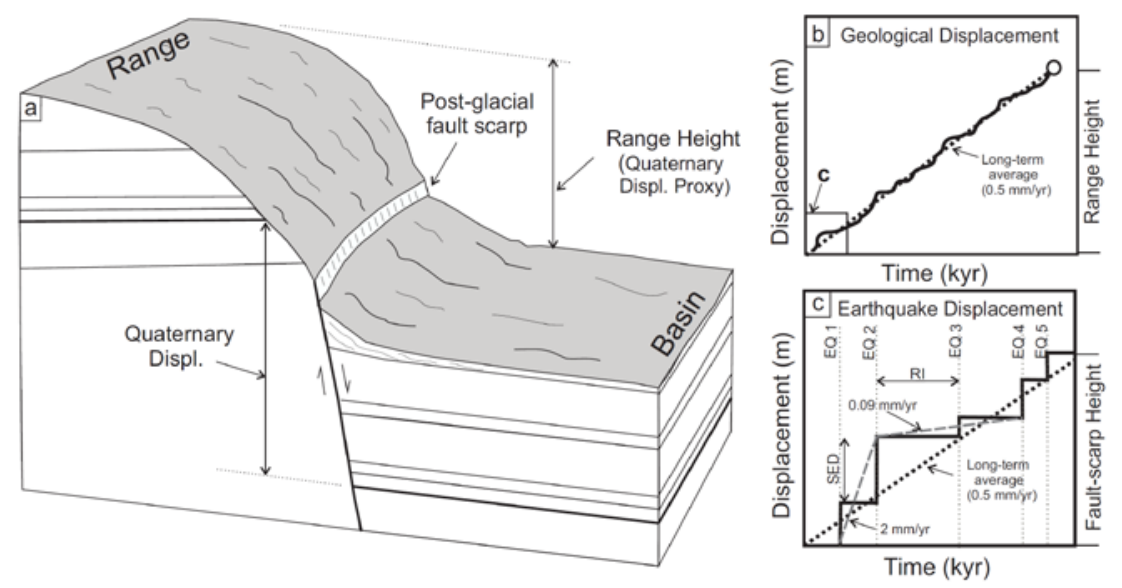

Figure 1

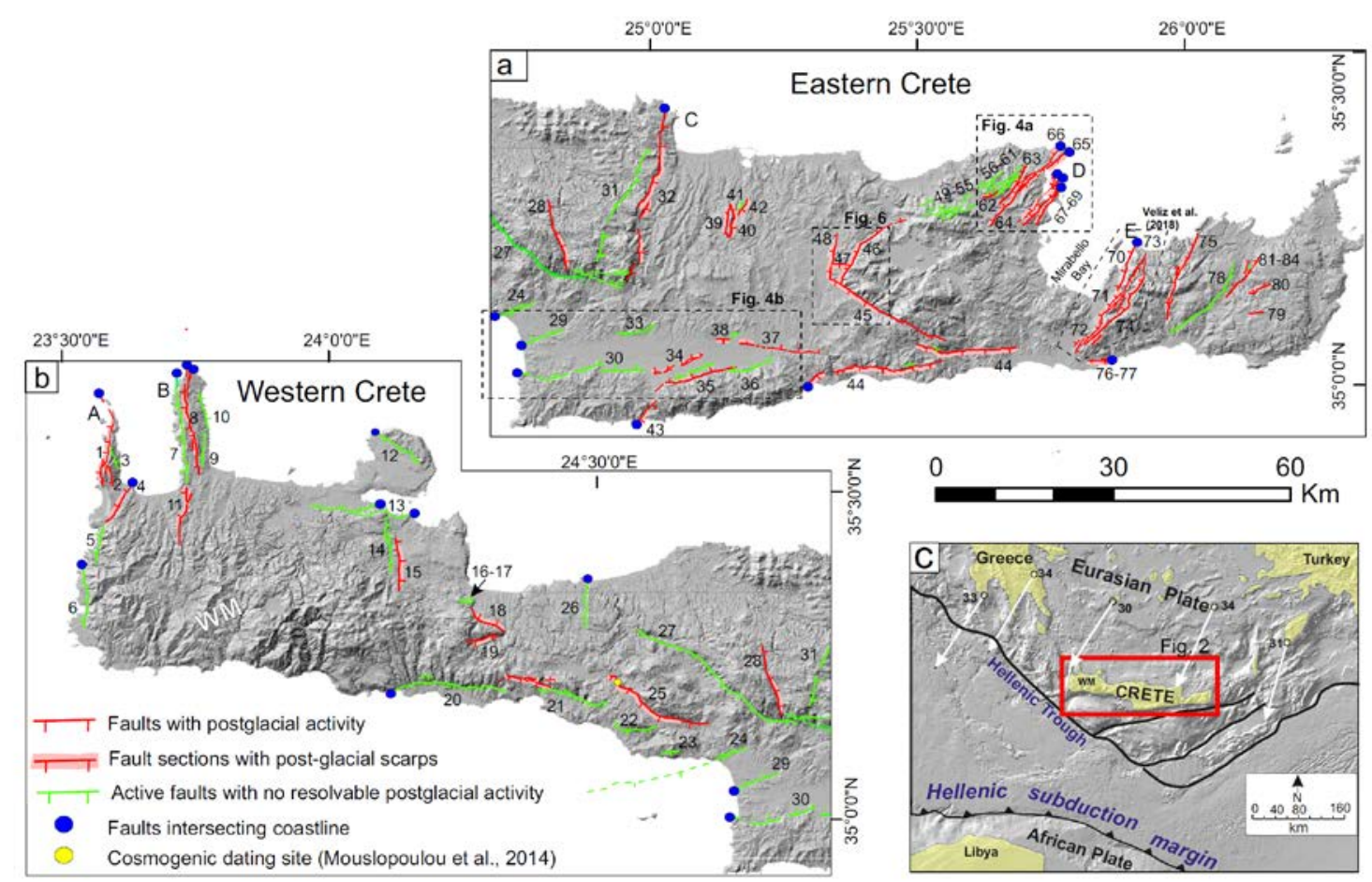

Figure 2 

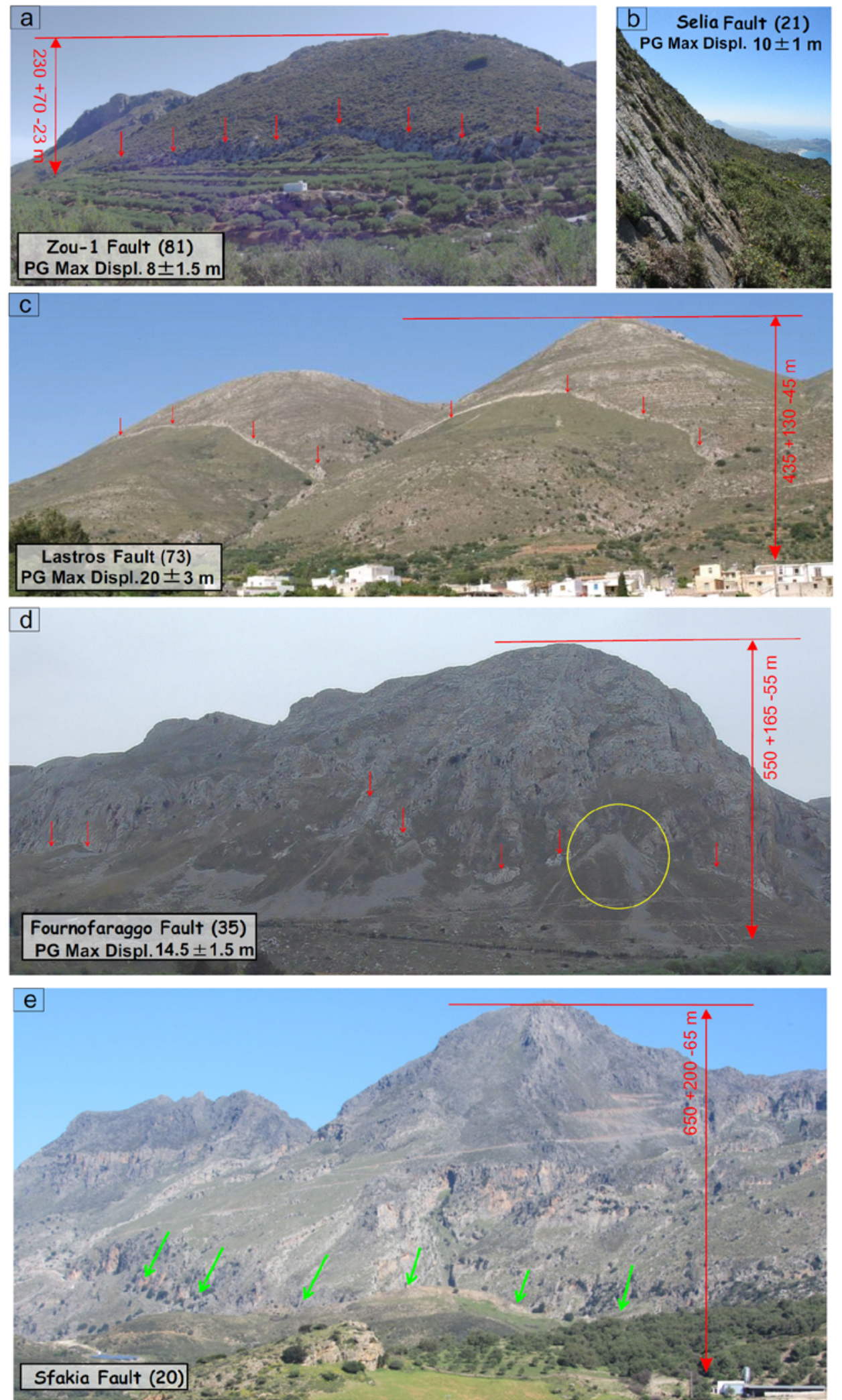

\section{Figure 3}


a

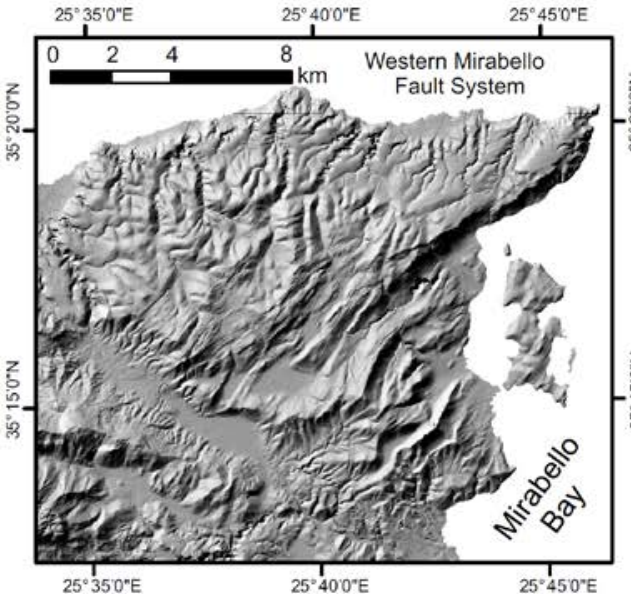

I Faults with activity within the last $16.5 \mathrm{kyr}$

T Fault sections with post-glacial scarps

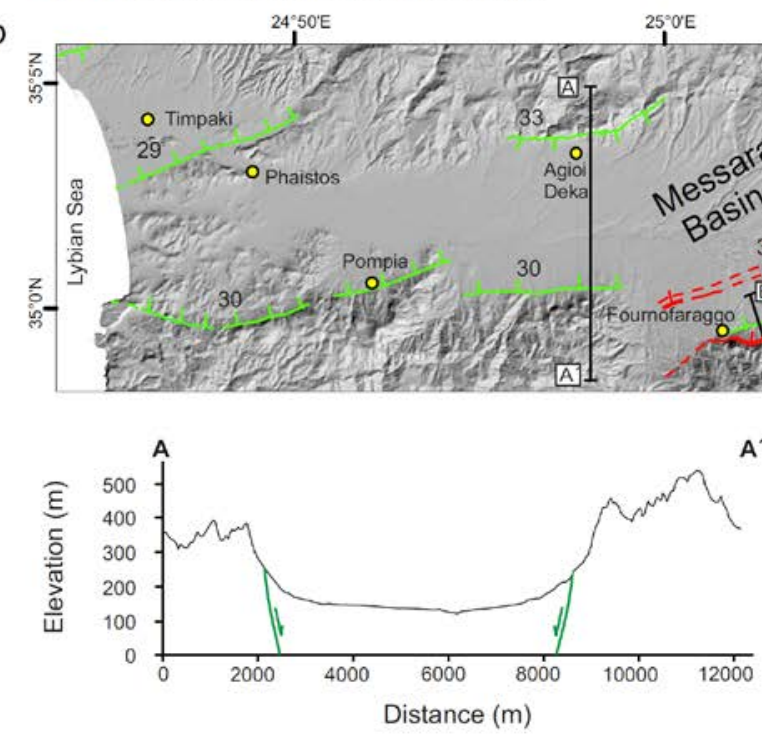

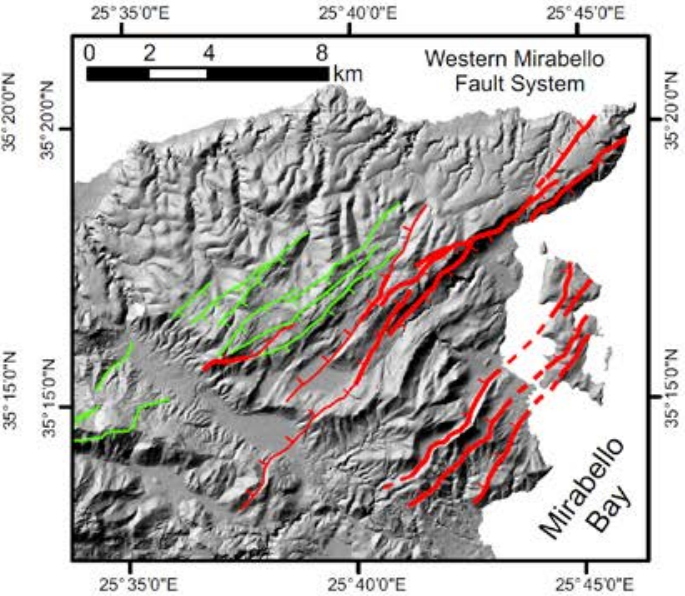
Active faults with no resolvable activity in the last $16.5 \mathrm{kyr}$ 25:10 E 

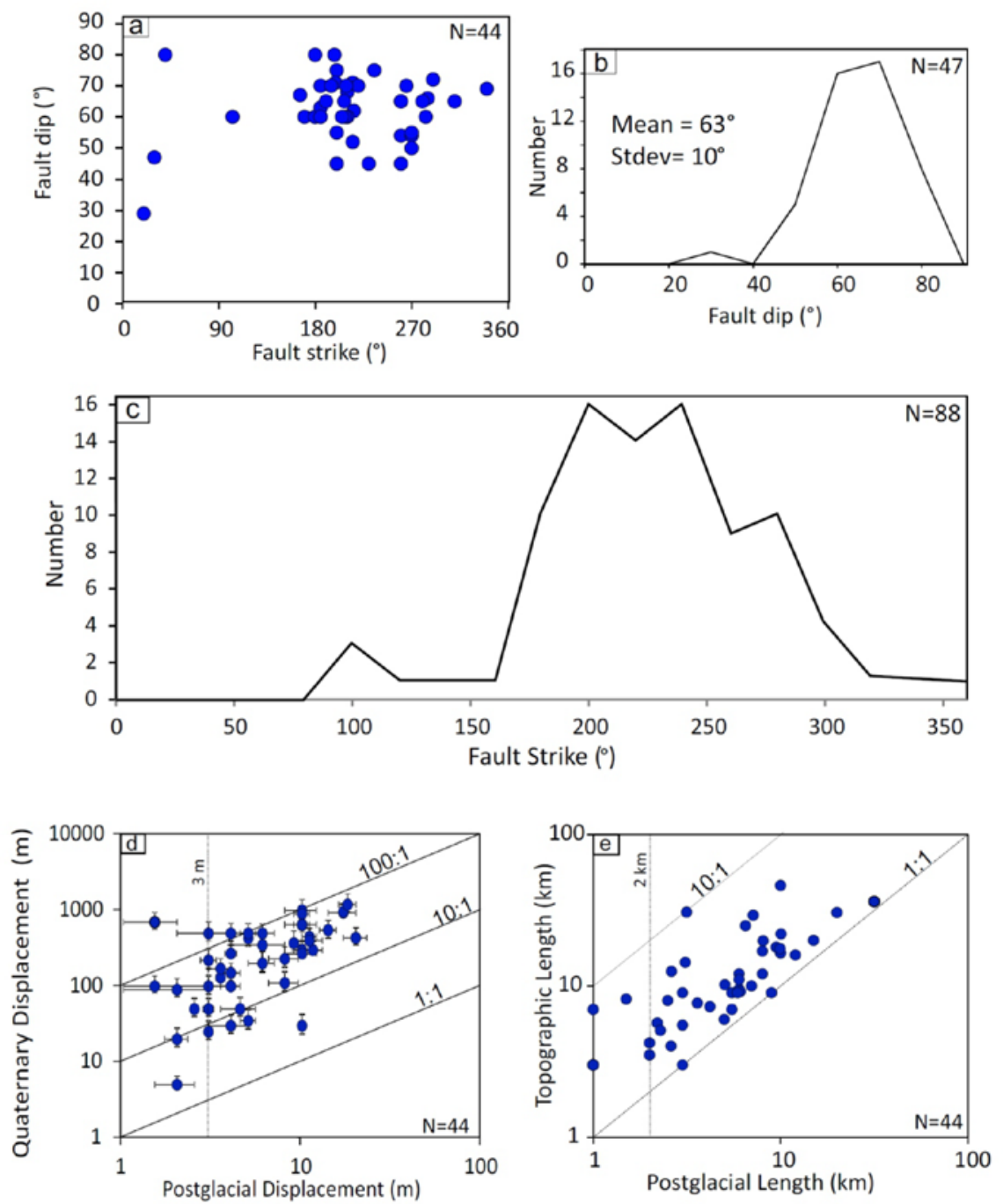

Figure 5 

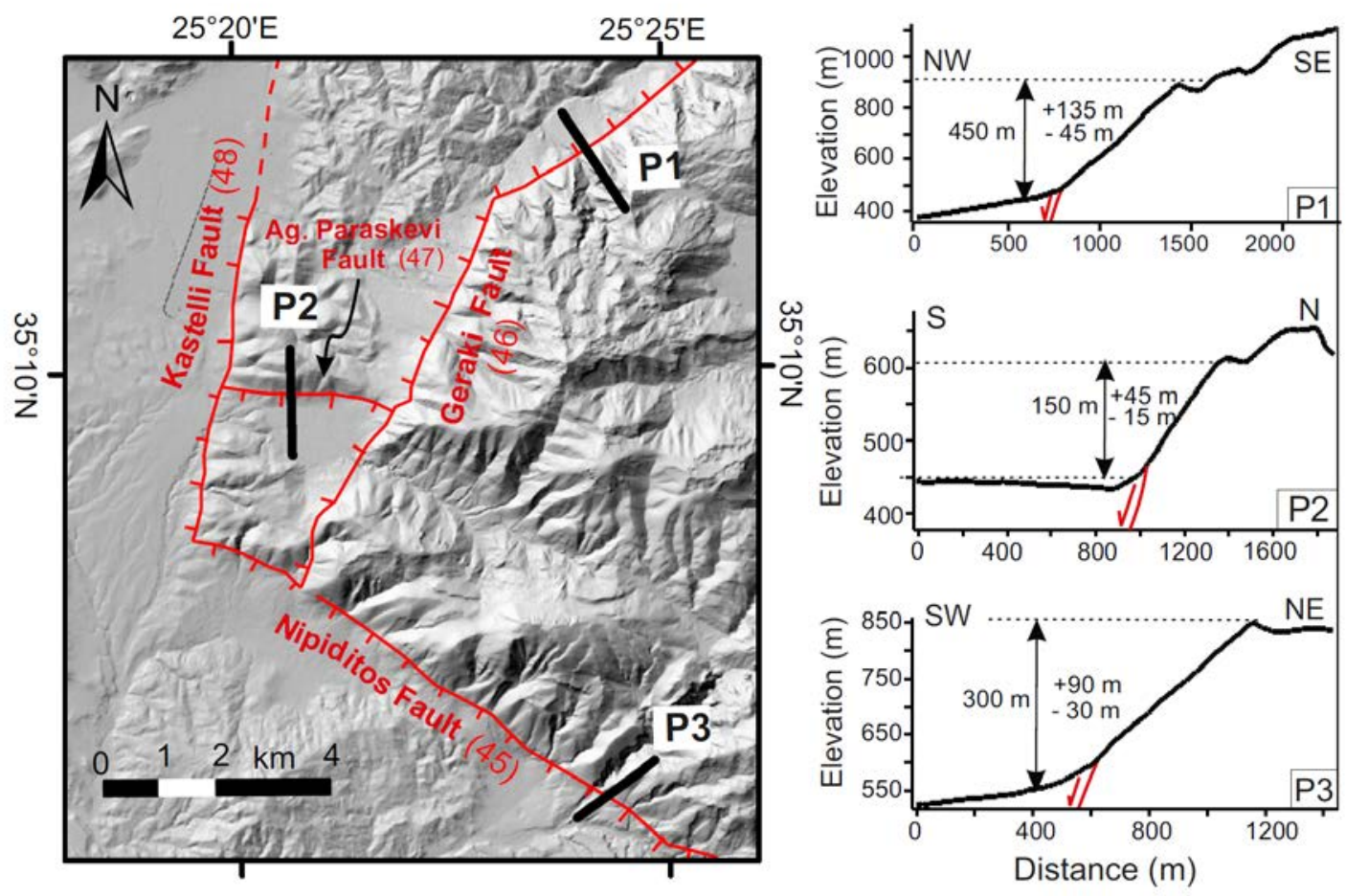

Figure 6
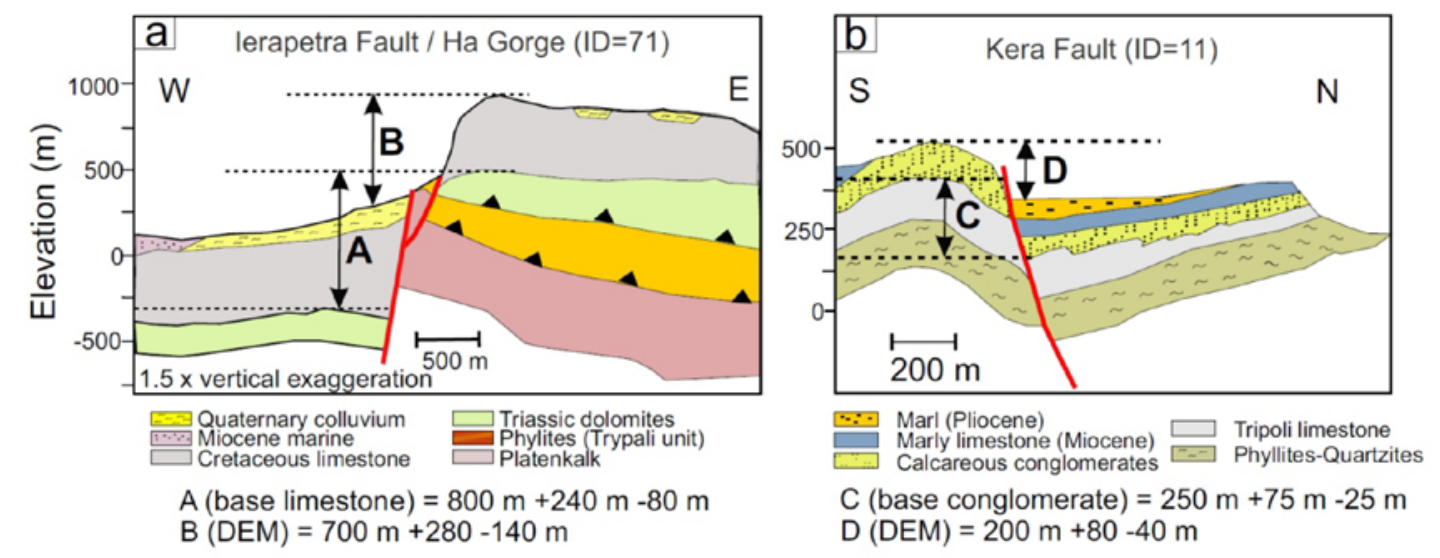

Figure 7 

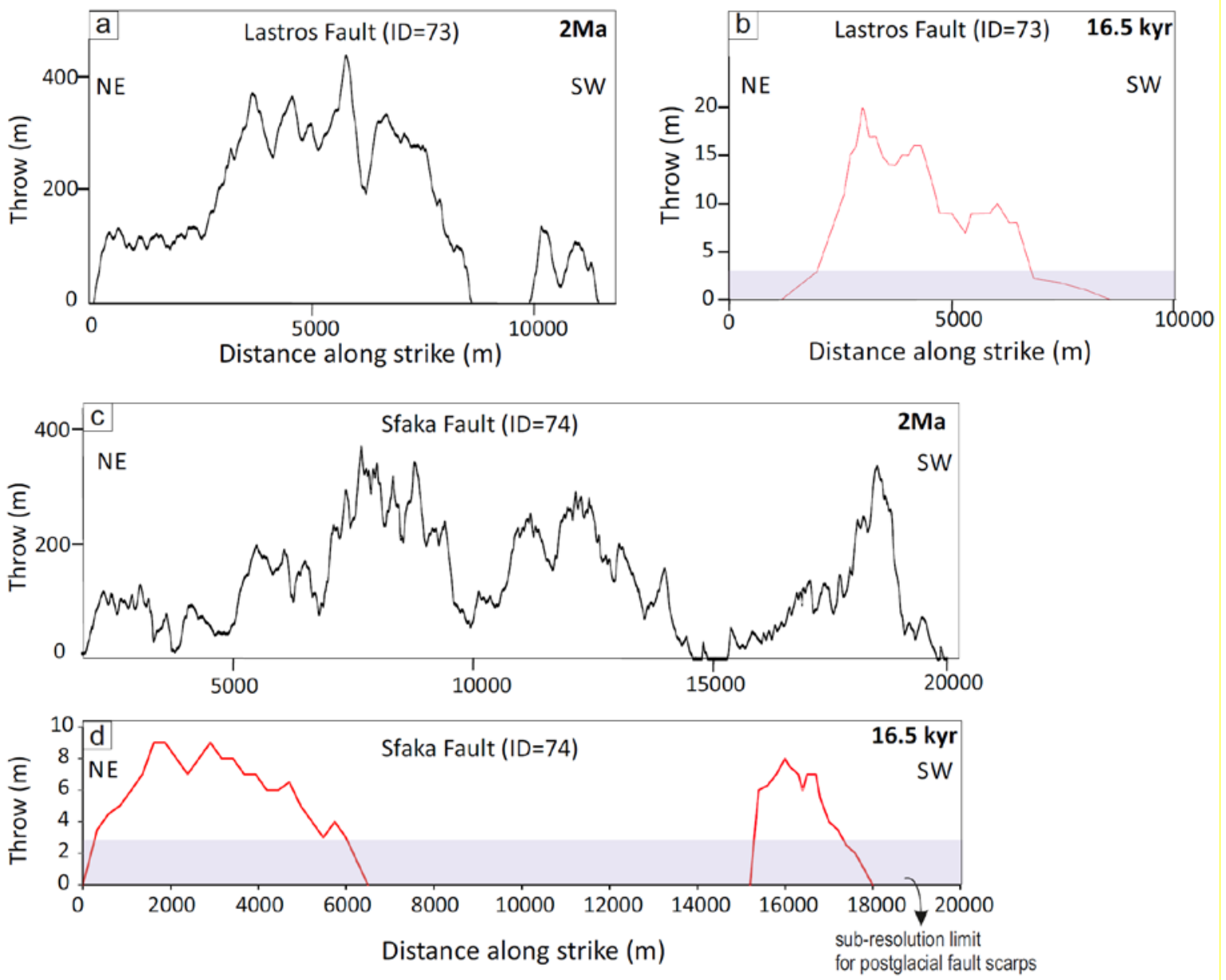

Figure 8 

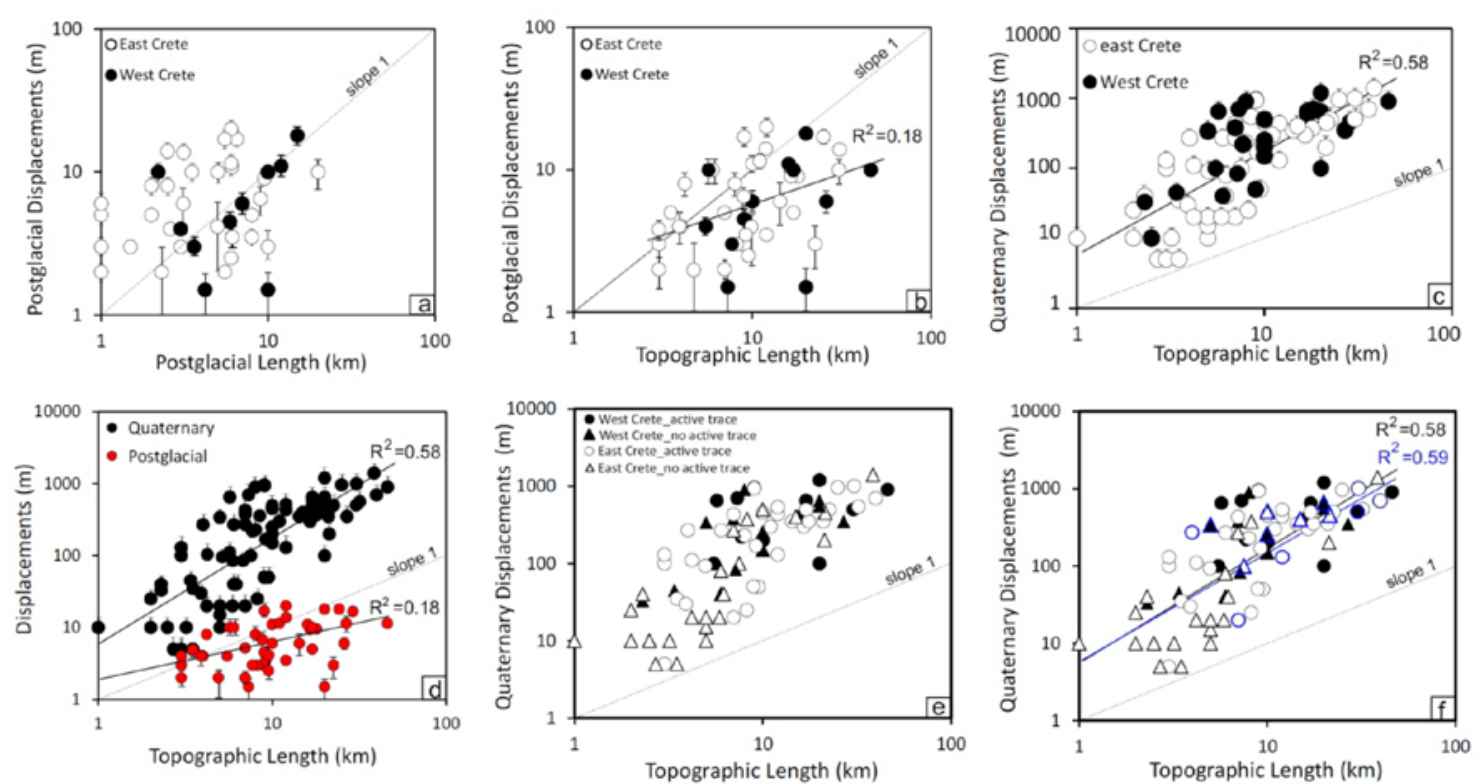

Figure 9

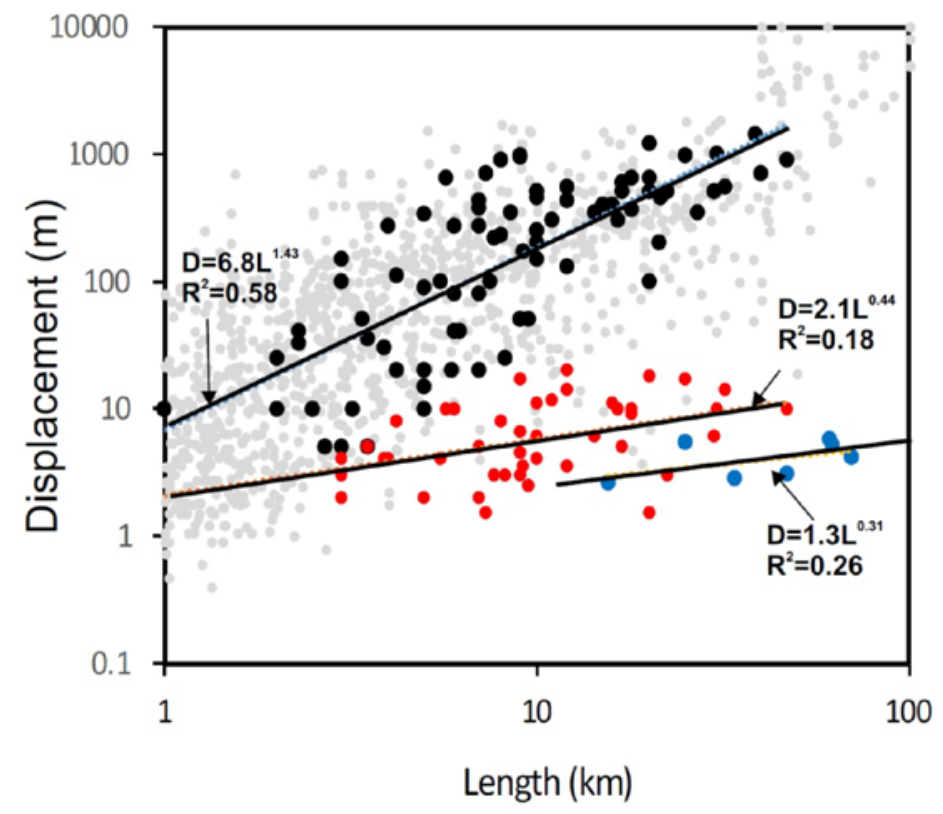

Figure 10 

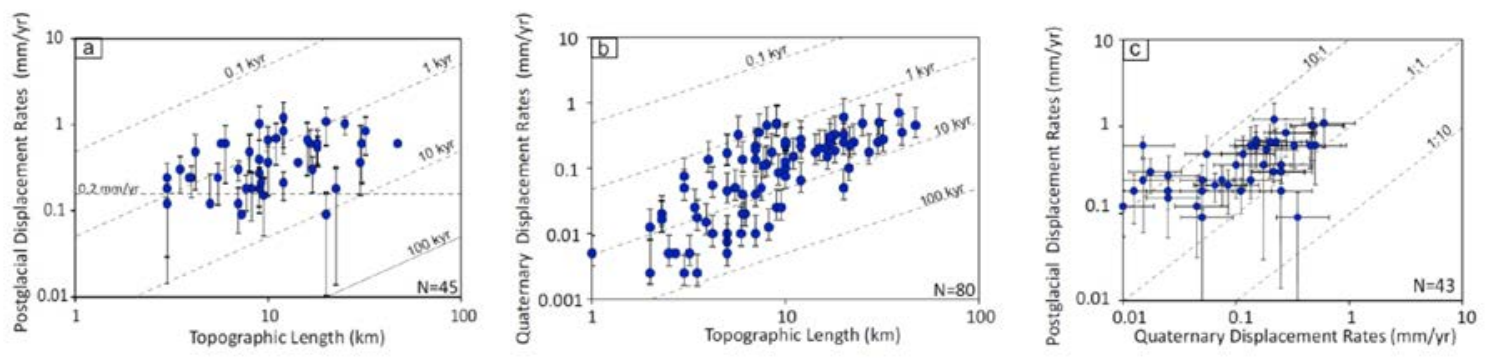

Figure 11
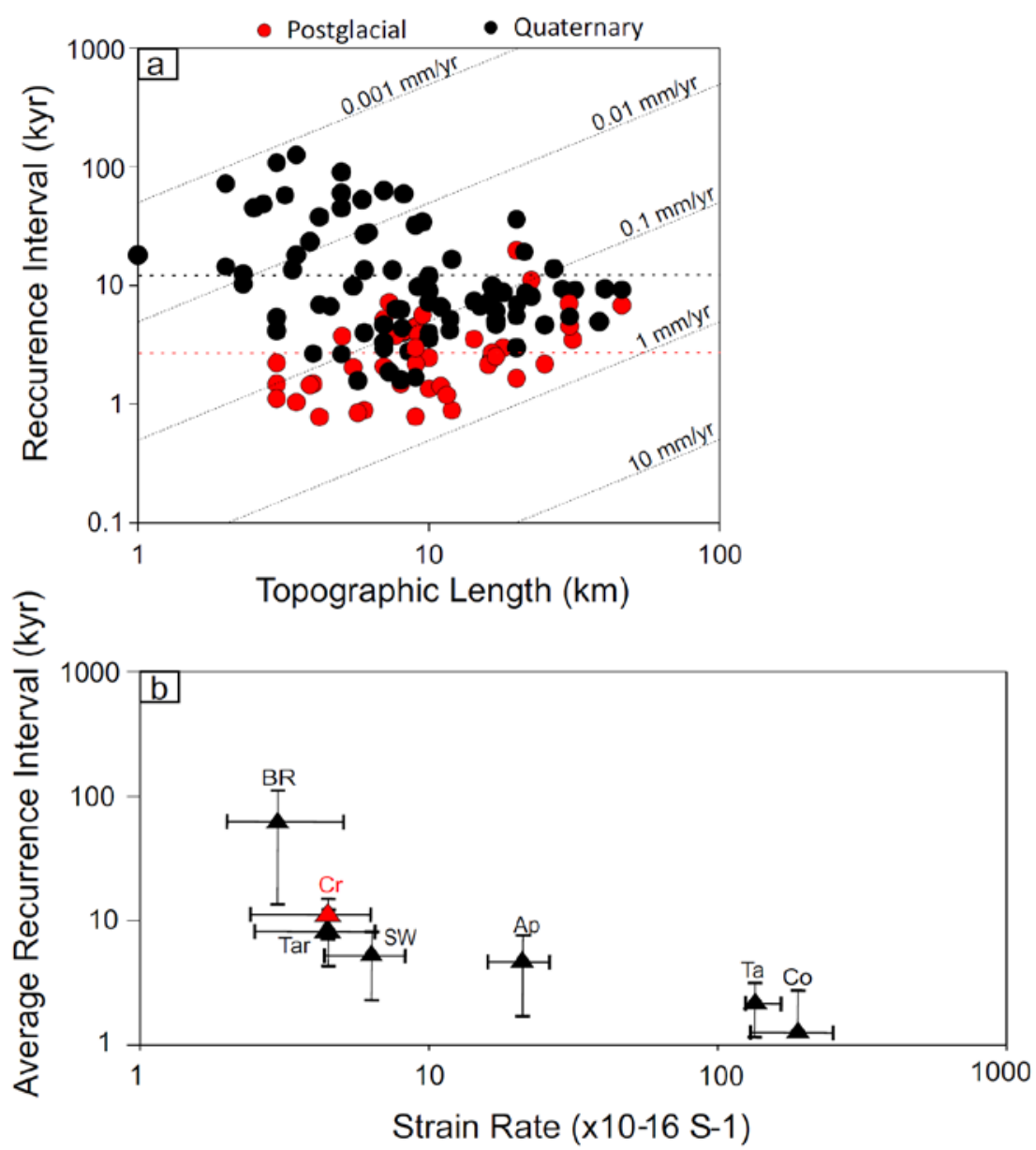

Figure 12 


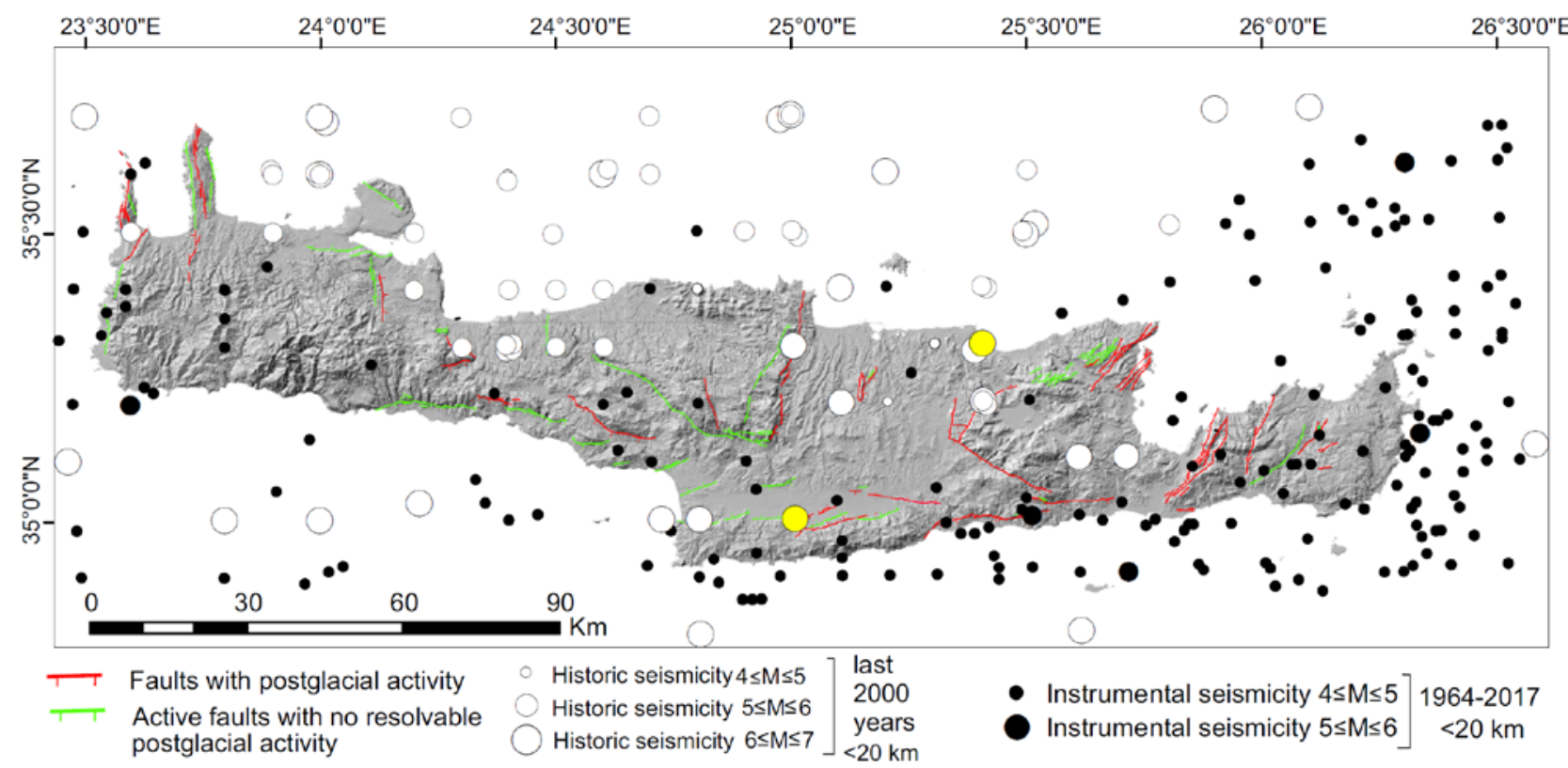

Figure 13 